\title{
Article \\ Prediction of Compressive Strength of Rice Husk Ash Concrete through Different Machine Learning Processes
}

\author{
Ammar Iqtidar 1,*(D), Niaz Bahadur Khan ${ }^{2}$, Sardar Kashif-ur-Rehman ${ }^{1}$, Muhmmad Faisal Javed ${ }^{1} \mathbb{1}$, \\ Fahid Aslam ${ }^{3}(\mathbb{D})$, Rayed Alyousef ${ }^{3}(\mathbb{D})$, Hisham Alabduljabbar ${ }^{3}$ and Amir Mosavi ${ }^{4,5, *(D)}$ \\ 1 Department of Civil Engineering, Abbottabad Campus, COMSATS University Islamabad, \\ Abbottabad 22060, Pakistan; skashif@cuiatd.edu.pk (S.K.-u.-R.); arbabfaisal@cuiatd.edu.pk (M.F.J.) \\ 2 School of Mechanical \& Manufacturing Engineering, National University of Sciences \& Technology, \\ Islamabad 44000, Pakistan; niaz.bahadur@smme.nust.edu.pk \\ 3 Department of Civil Engineering, College of Engineering in Al-Kharj, Prince Sattam Bin Abdulaziz University, \\ Al-Kharj 11942, Saudi Arabia; f.aslam@psau.edu.sa (F.A.); r.alyousef@psau.edu.sa (R.A.); \\ h.alabduljabbar@psau.edu.sa (H.A.) \\ 4 Faculty of Civil Engineering, Technische Universitat Dresden, 01069 Dresden, Germany \\ 5 John von Neumann Faculty of Informatics, Obuda University, 1034 Budapest, Hungary \\ * Correspondence: FA16-BCV-016@cuiatd.edu.pk (A.I.); amir.mosavi@mailbox.tu-dresden.de (A.M.)
}

\section{check for} updates

Citation: Iqtidar, A.; Bahadur Khan, N.; Kashif-ur-Rehman, S.; Faisal Javed, M.; Aslam, F.; Alyousef, R.; Alabduljabbar, H.; Mosavi, A. Prediction of Compressive Strength of Rice Husk Ash Concrete through Different Machine Learning Processes. Crystals 2021, 11, 352. https:// doi.org/10.3390/cryst11040352

Academic Editors: Shujun Zhang and Yifeng Ling

Received: 13 February 2021

Accepted: 22 March 2021

Published: 29 March 2021

Publisher's Note: MDPI stays neutral with regard to jurisdictional claims in published maps and institutional affiliations.

Copyright: (C) 2021 by the authors Licensee MDPI, Basel, Switzerland. This article is an open access article distributed under the terms and conditions of the Creative Commons Attribution (CC BY) license (https:// creativecommons.org/licenses/by/ $4.0 /)$.

\begin{abstract}
Cement is among the major contributors to the global carbon dioxide emissions. Thus, sustainable alternatives to the conventional cement are essential for producing greener concrete structures. Rice husk ash has shown promising characteristics to be a sustainable option for further research and investigation. Since the experimental work required for assessing its properties is both time consuming and complex, machine learning can be used to successfully predict the properties of concrete containing rice husk ash. A total of 192 data points are used in this study to assess the compressive strength of rice husk ash blended concrete. Input parameters include age, amount of cement, rice husk ash, super plasticizer, water, and aggregates. Four soft computing and machine learning methods, i.e., artificial neural networks (ANN), adaptive neuro-fuzzy inference system (ANFIS), multiple nonlinear regression (NLR), and linear regression are employed in this research. Sensitivity analysis, parametric analysis, and correlation factor $\left(\mathrm{R}^{2}\right)$ are used to evaluate the obtained results. The ANN and ANFIS outperformed other methods.
\end{abstract}

Keywords: rice husk ash; sustainable concrete; artificial neural networks; multiple linear regression; eco-friendly concrete; green concrete; sustainable development; artificial intelligence; data science; machine learning

\section{Introduction}

The world is making progress by leaps and bounds. New technologies and innovations are being introduced every day in every field. These advancements have altered the course of human history. One of the main aspects that has played a crucial role in shaping modern human civilization is infrastructure. From caves, mankind has started to live in strong and pleasing dwellings made by their own creative and innovative minds. Still, today infrastructure is considered to be the main element for progress in any country. The construction material that is used in abundance throughout the world for the construction of infrastructure is cement. However, along with the advantages of cement there are also certain adverse effects. Cement is said to be responsible for seven percent of the total carbon dioxide emissions worldwide [1]. It produces carbon dioxide while reacting when water is added to it. Secondly, a high temperature is required during the production of cement [2]. This high temperature is achieved by burning fossil fuels which increase the carbon footprint of cement. Our planet earth is suffering from problems of grave danger. Environmental deterioration and global warming are some of these alarming issues. If not 
controlled in due time, these problems will push the earth to the brink of extinction. One of the major causes of environmental degradation and global warming is said to be the emission of carbon dioxide from different products and processes $[3,4]$. Since cement is a crucial contributor to the total carbon dioxide emissions of the world, the importance of infrastructure cannot be undermined. It must be replaced with some other material that has a smaller carbon footprint as well as possessing the same or better properties than cement.

The materials that replicate the properties of ordinary Portland cement (OPC) are known as secondary cementitious materials (SCMs). They have smaller carbon dioxide emission rates [5]. SCMs are generally waste materials and byproducts of different industries. These materials become sources of various types of pollution if not discarded or utilized properly. SCMs can be used in different proportions and combinations to replicate the desired properties of OPC. Some of the SCMs are fly ash (FA), corn cob ash (CCA), sugarcane bagasse ash (SCBA), rice husk ash (RHA), ground granulated blast furnace slag (GGBFS), etc [6-9]. RHA is one of the SCMs obtained from the agricultural waste of rice crop. Rice grains are covered in rice husks (RH) which are used as a fuel to boil paddy in rice mills. RHA is obtained after utilizing rice husks as fuel. It contains more than 90 percent silica and can be used successfully as an SCM to synthesize concrete [10]. An illustration of the chemical composition of RHA is shown in Figure 1 [11]. Ameri et al. [12] conducted a research on concrete containing RHA. It was found that concrete containing RHA showed a vigorous increase in early compressive strength. However, by increasing the RHA content by more than 15 percent, the compressive strength was decreased. This is attributed to the excess amount of silica present in RHA which remains unreacted. The compressive strength of concrete with RHA as an SCM was 9, 12, 13, and 16 percent higher than that of control mix. Similarly, Chao Lung et al. [13] incorporated RHA in concrete and concluded that concrete containing RHA showed a strength 1.2 to 1.5 times greater than that of the control mix. Chindaprasirt et al. [14] tested the concrete containing RHA for sulphate attack resistance and reported that concrete containing RHA proved to be highly effective against sulphate attack. It was reported by Thomas et al. [15] in a review paper that concrete containing RHA has a dense microstructure, so it can be used to reduce the water absorption of concrete by up to 30 percent. Rattanachu et al. [16] conducted research in which grounded RHA was used with steel reinforcements. It was observed that the use of RHA in the presence of steel resisted the corrosion of steel due to the fine structure of RHA. Thus, several studies have been made on environmental impact of RHA. They are reported in Table 1:

Table 1. Environmental impact of rice husk ash (RHA).

\begin{tabular}{ccc}
\hline Material in Which RHA Is Used & Results & Reference \\
\hline Concrete & Utilization of RHA results in reduction of global & {$[17]$} \\
Mortar & warming potential (GWP) & {$[18]$} \\
Concrete & Use of RHA results in reduction of harmful & environmental impacts \\
Concrete blocks & RHA aids in reducing carbon footprint of concrete & {$[19]$} \\
Utilization of RHA shows positive environmental & results & {$[20]$}
\end{tabular}

Hence, RHA can be utilized successfully as a cementitious material. RHA does not produce excessive amount of carbon dioxide. It can be used as a structural concrete. Not only does it contribute towards the strength of the concrete but also towards the long term durability properties of concrete [21]. 


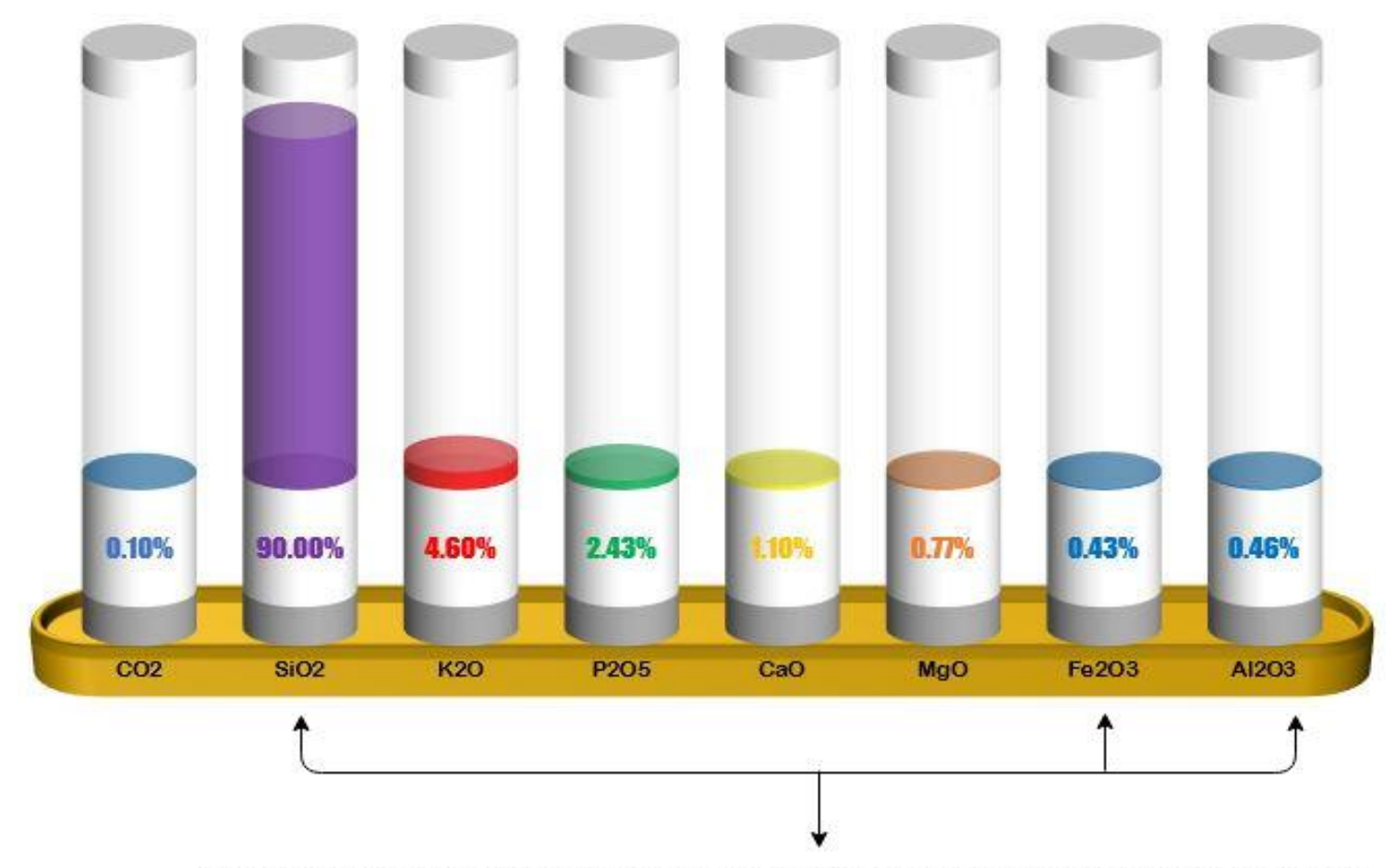

Sum of oxides of Silica, Alumina and Ferrous $>70$ percent so RHA is a pozzolona as per ASTM C618

Figure 1. Chemical composition of RHA.

The rate of environmental deterioration does not allow one to spend an extensive amount of time on research and development of RHA blended concrete (RBC). Consequently, extensive lab works cannot be carried out on RBC. Along with that there is always an uncertainty regarding the mix design of RBC. This is due to the hygroscopic nature of RHA. Therefore, to predict the properties of different SCMs, artificial intelligence (AI) is being used throughout the globe. AI is used by different researchers to assess and predict the strength of concrete mixes. Table 2 lists the different previous studies conducted on SCMs to predict different properties. Different techniques such as artificial neural networks (ANN), LR, adaptive neuro-fuzzy inference system (ANFIS), and MNLR are used to successfully model and predict different properties of materials [22,23].

As AI research depends on mathematical modelling and parameters, it is a complex programming work and needs great optimization and care. Therefore, four programming techniques are being used to predict the compressive strength of RHA-based concrete in this research. These techniques are ANFIS, ANN, MNLR, and LR. To achieve the targeted accuracy and to cater the complexity of programming these four techniques will be compared with each other. A vast database of peer reviewed literature is used to model the prediction of compressive strength. 
Table 2. Some recent studies using AI.

\begin{tabular}{|c|c|c|c|c|}
\hline Material Used & No. of Data Points & Property Predicted & Modelling Technique Used & Reference \\
\hline SCBA & 65 & Compressive strength & $\begin{array}{c}\text { GEP, Multiple Linear Regression } \\
\text { (MLR), Multiple Nonlinear Regression } \\
\text { (MNLR) }\end{array}$ & [22] \\
\hline $\begin{array}{l}\text { Silica fume (SF) and } \\
\text { zeolite }\end{array}$ & 18 & Compressive Strength & ANN & [23] \\
\hline $\begin{array}{l}\text { Recycled concrete } \\
\text { aggregate }\end{array}$ & 17 & Compressive strength & $\begin{array}{c}\text { ANN, Response Surface Methodology } \\
\text { (RSM) }\end{array}$ & [24] \\
\hline $\begin{array}{l}\text { Recycled rubber } \\
\text { concrete }\end{array}$ & 72 & Compressive strength & $\begin{array}{c}\text { ANN, MNLR, ANFIS, Support vector } \\
\text { machine (SVM) }\end{array}$ & [25] \\
\hline Cellular concrete & 99 & Compressive strength & $\begin{array}{c}\text { Backpropagation Neural Network } \\
\text { (BPNN) }\end{array}$ & [26] \\
\hline $\begin{array}{l}\text { Fly ash (FA) and blast } \\
\text { furnace slag (BFS) }\end{array}$ & 135 & Compressive strength & ANN & [27] \\
\hline Foamed concrete & 91 & Compressive strength & Extreme Learning Machine (ELM) & [28] \\
\hline Recycled aggregates & 74 & Compressive strength & ANN Convolutional Neural Network & [29] \\
\hline Rubberized concrete & 112 & Compressive strength & ANN & [30] \\
\hline $\begin{array}{l}\text { Steel fiber added } \\
\text { lightweight concrete }\end{array}$ & 126 & Compressive strength & ANN & {$[31]$} \\
\hline $\begin{array}{c}\text { Fiber reinforced } \\
\text { polymer concrete (FRP) }\end{array}$ & 98 & Shear strength & ANN & [32] \\
\hline FRP & 84 & Shear strength & ANN & [33] \\
\hline $\begin{array}{l}\text { High strength concrete } \\
\text { (HSC) }\end{array}$ & 187 & Compressive strength & ANN & [34] \\
\hline
\end{tabular}

\section{Data Collection}

To predict the compressive strength (CS) of RHA, mathematical models are developed using a dataset of 192 data points from the vast literature review and existing studies on machine learning [12,13,35-39]. These data were collected through google Scopus. The constituents of concrete include RHA, OPC, aggregates, super plasticizer (SP), and water. The type of cement and curing methodology used in all the mixes is same. The CS of cubic specimens is converted into CS of cylinders by using 0.8 as a factor (as per BS 1881: Part 120:1983). The only output parameter in this study is compressive strength. The input parameters consist of main variables such as percentage of SP, curing age (CA), quantity of water used (W), amount of OPC (OPCP), quantity of aggregates (AGG), and amount of RHA (RHAP). Moreover, the description of collected data and its statistics are given in Table 3.

Table 3. Statistical analysis of input data.

\begin{tabular}{ccccccc}
\hline Parameters & Mean & Standard Deviation & Kurtosis & Skewness & Minimum & Maximum \\
\hline Input parameters & & & & & & \\
Age $($ days) & 34.57 & 33.52 & -1.02 & 0.75 & 1 & 90 \\
Plain cement $\left(\mathrm{kg} / \mathrm{m}^{3}\right)$ & 409.02 & 105.47 & 3.66 & 1.55 & 249 & 783 \\
RHA $\left(\mathrm{kg} / \mathrm{m}^{3}\right)$ & 62.33 & 41.55 & 0.07 & 0.44 & 0 & 171 \\
Water $\left(\mathrm{kg} / \mathrm{m}^{3}\right)$ & 193.54 & 31.93 & -0.74 & -0.42 & 120 & 238 \\
Super plasticizer $\left(\mathrm{kg} / \mathrm{m}^{3}\right)$ & 3.34 & 3.52 & -0.82 & 0.69 & 0 & 11.25 \\
Aggregates $\left(\mathrm{kg} / \mathrm{m}^{3}\right)$ & 1621.51 & 267.77 & -0.27 & -0.74 & 1040 & 1970 \\
Response & & & & & & 16 \\
Experimental compressive strength & 48.14 & 17.54 & 0.75 & 0.83 & & 104.1 \\
(MPa) & & & & &
\end{tabular}




\section{Methodology}

The methodology section provides a brief detail about the approaches being made to determine the CS of concrete mathematically as shown in Figure 2. First, the AI processes used in this research are explained. The results obtained from AI data processing techniques are assessed for validity by different statistical parameters.

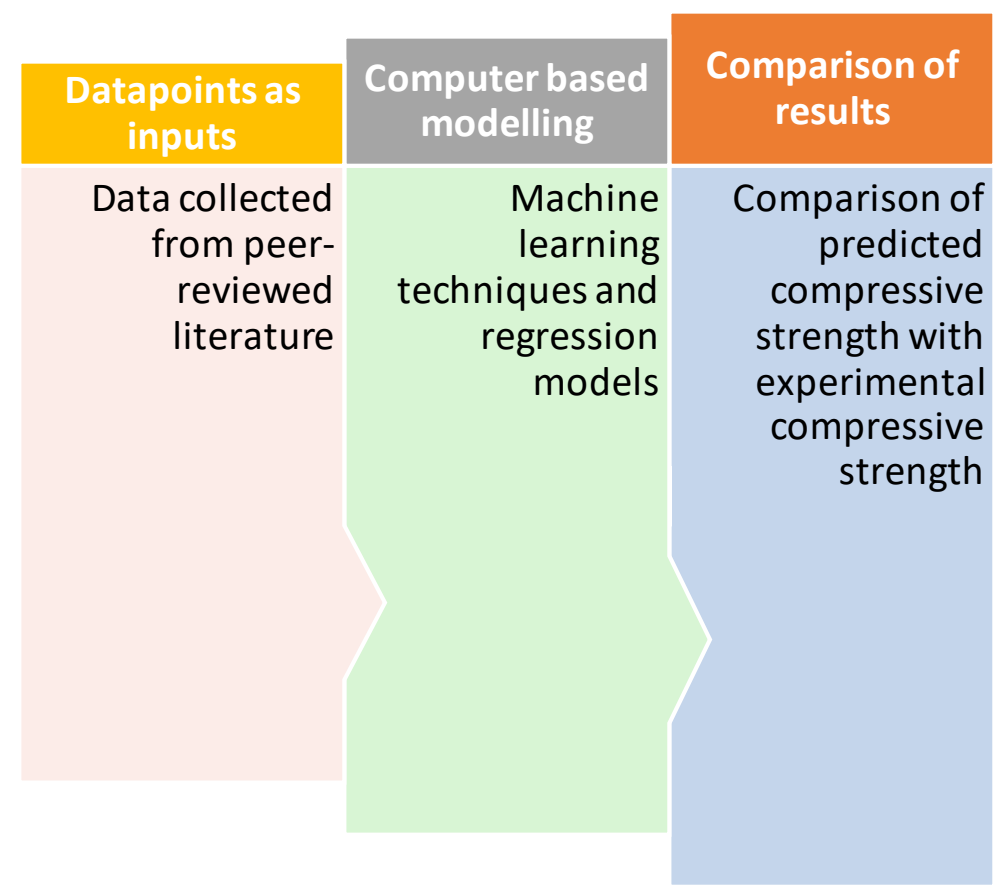

Figure 2. Adopted methodology for study.

\subsection{Modeling Techniques}

Machine learning-based modeling has been used in the past to predict the different mechanical properties of materials [40-42]. These types of modeling techniques can be utilized to develop models for prediction of a property of material. They do not need any knowledge of the rudimentary experimental processes. This section of paper provides a brief introduction of the predictive models used in this study. These models are as follow:

\subsubsection{ANN}

ANN is an artificial data analyzing technique. It is inspired by the learning capability of human brain. The most widely used type of ANN is feedforward back propagation (FFBP). As evident from Figure 3, an FFBP consists of at least three layers, namely, the input layer, hidden layer, and output layer. The nodes of these layers are connected in a proper sequence along with some weights. The input layer nodes do not perform any function on input data. Their function is to just receive the data from outside. It is a hidden layer where data are biased, weighted, and summed up. These processed data are then sent out to the output layers $[43,44]$.

There are basically two types of FFBP, namely, single layer perceptron (SLP) and multiple layers perceptron (MLP). Both types of FFBP have their own advantages and disadvantages. Alhough the SLP is simple and easy to use, it cannot handle nonlinear relations. On the other hand, MLP are complex, but they can be applied to nonlinear relations. 


\section{Input variables}

\section{Outputs}

\section{Concealed layers/ Blackbox}

Figure 3. Illustration of ANN.

Mathematically, an MLP operates in following way:

Step 1: The inputs are summed and weighted as

$$
s_{j}=\sum_{i=1}^{n} \omega_{i j} I_{i}+b j j=1,2,3, \ldots \ldots, \mathrm{h}
$$

where $n=$ number of total inputs, $I_{i}=$ current input number, $\omega_{i j}=$ weight between the previous layer, and the $j$ th neuron and $b$ are used to define the termination of process.

Step 2: This step includes an activation function. There are various types of activation functions such as sigmoid, ramp, and Gaussian functions. However, this research utilizes sigmoid function which is defined as

$$
s_{j}=\frac{1}{1+e^{-s_{j}}} j=1,2,3, \ldots \ldots \ldots, \mathrm{h}
$$

Step 3: This represents the final outputs. The final outputs depend on the outputs calculated by hidden nodes. The final outcome can be expressed as

$$
\begin{gathered}
O_{k}=\sum_{j=1}^{h}\left(\omega_{j k} \cdot s_{j}\right)+b_{k}^{\prime}, k=1,2, \ldots, m \\
O_{k}=\operatorname{sigmoid}\left(O_{k}\right)=\frac{1}{\left(1+e^{-O_{k}}\right)}, k=1,2, \ldots, m
\end{gathered}
$$

In above equation, $\omega_{j k}=$ weighted connection between $k$ th output node to $j$ th hidden node. Similarly, $b_{k}^{\prime}=$ bias output of $k$ th output node.

In this research, 70 percent of the data points are selected randomly for the training of data, and 30 percent for validation.

\subsubsection{ANFIS}

ANFIS is a technique that utilizes the combined effect of artificial neural networks and fuzzy logic [45]. Figure 4 shows a brief illustration of the ANFIS technique. An artificial neural network is used to minimize the chances of error in the output data. Thus, the fuzzy logic is implied to demonstrate the expert knowledge [42]. Fuzzy logic rules are applied as if-then while mathematically programming for the desired input and output datasets. An ANFIS model consists of five layers normally. These are (1) fuzzification, (2) set of rules, (3) normalization, (4) defuzzification, (5) aggregation. 


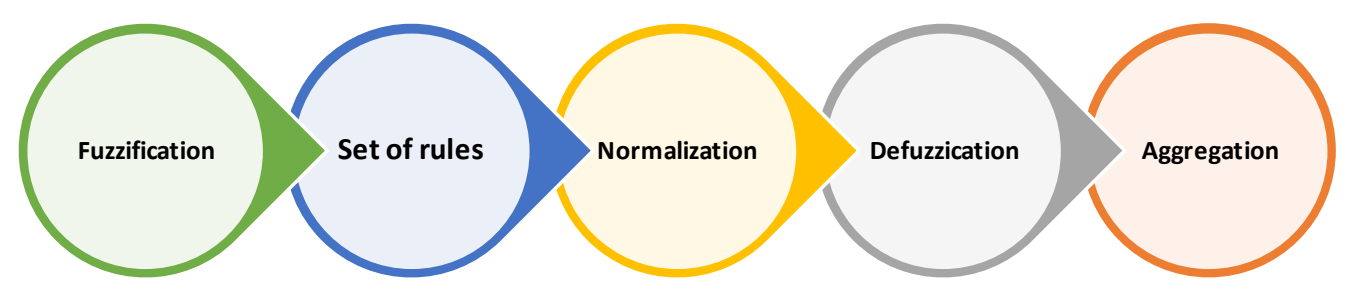

Figure 4. Illustration of adaptive neuro-fuzzy inference system (ANFIS).

Layer 1 is the fuzzification layer. It contains all the function members of the input variables. A Gaussian function is used in this layer to predict the outcome. Mathematically, it can be expressed as

$$
\mu_{u i}(x)=\exp \left[-\frac{\left(x-a_{i}\right)}{2 \varepsilon_{i}^{2}}\right]
$$

where $a_{i}$ and $\varepsilon_{i}$ are parameters of a function membership.

Layer 2 contains nodes which send the output by multiplying the input by certain weightages. This layer utilizes the fuzzy AND logic by using the equation listed below:

$$
w_{i}=\mu_{u i}(x) \times \mu_{v i}(y)
$$

Layer 3 has an aim to normalize the data. It normalizes the functions of membership. It calculates the ratios between different firing strength using the following expression:

$$
\bar{w}=\frac{w_{i}}{\sum_{i} w_{i}}
$$

Layer 4 is known as the defuzzification layer. It contains nodes that conclude the fuzzy logic rules. This layer contains square nodes, which can be expressed by following function:

$$
\bar{w}_{i} f_{i}=w_{i} \times\left(m_{i} x+n_{i} y+r_{i}\right)
$$

where $m_{i}, n_{i}$, and $r_{i}$ are linear parameters.

Layer 5 has a function of aggregation. It sums up the previous layers and presents the final output mathematically as follows:

$$
\sum_{i} \bar{w} f_{i}=\frac{\sum_{i} w_{i} f_{i}}{\sum_{i} w_{i}}
$$

All the data points are used for the training of data.

Off the shelf functionality of MATLAB is used for ANN and ANFIS techniques in this research.

\subsubsection{MNLR}

MNLR is a technique which is used to model a random nonlinear relationship between the dependent and independent variables. The following equation represents the MNLR [41]:

$$
Y=a+\beta_{1} X_{i}+\beta_{2} X_{j}+\beta_{3} X_{i}^{2}+\beta_{4} X_{j}^{2}+\ldots \ldots+\beta_{k} X_{i} X_{j}
$$

where $a=$ intercept, $\beta=$ slope or coefficient, $K=$ number of observations. The above equation can make an estimate for the value of $Y$ for each value of $X$.

\subsubsection{LR}

LR is a technique in which there is linear relationship between the dependent and independent variables. It can be represented mathematically as follows:

$$
Y=a+\beta_{1} X_{1}+\beta_{2} X_{2}+\beta_{3} X_{3}+\ldots \ldots+\beta_{i} X_{i}
$$


The above equation can be utilized to find values of $Y$ for each input value $X$.

In above equations of MNLR and LR, " $Y$ " stands for compressive strength of RHA. Similarly, the values of " $X$ " represents inputs which are age, water content, RHA content, SP content, and the percentage of aggregates.

The models are developed in Microsoft Excel by authors for MNLR and LR techniques using the above equations.

\section{Results}

A total of 192 data points are used for all the models and techniques. A total of 134 data points are used for training, and 58 data points for validation. The results of machine learning techniques and regression models are given in Appendix A.

\subsection{ANN}

Parametric adjustments are made before running the proposed ANN model. These parameters include number of hidden layers, total number of neurons per hidden layer, training function for neural networks, epochs, and maximum number of iterations. These parameters are determined through the hit and trial method in this research. The details of the parametric adjustment are given in Table 4 .

Table 4. Parametric adjustment of the developed model.

\begin{tabular}{cc}
\hline Parameters & Description \\
\hline Total number of hidden layers & 2 \\
Maximum number of neurons per hidden layer & 10 \\
Training function & Levenberg-Marquardt \\
Epochs & 3 \\
Training completed at epoch & 2 \\
\hline
\end{tabular}

MATLAB was used to predict the compressive strength of RBC through ANN. ANN gave the results which were closest to the experimental results. The same can be verified through the statistical parameters of ANN.

It is noteworthy that the correlation factor for ANN predicted CS $\left(R^{2}=0.98\right)$ is quite high. The prediction result for ANN is plotted in Figure 5.

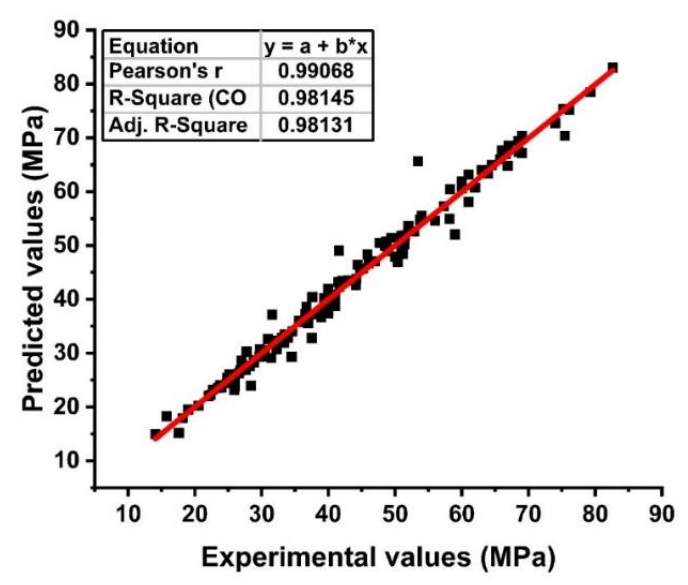

(a)

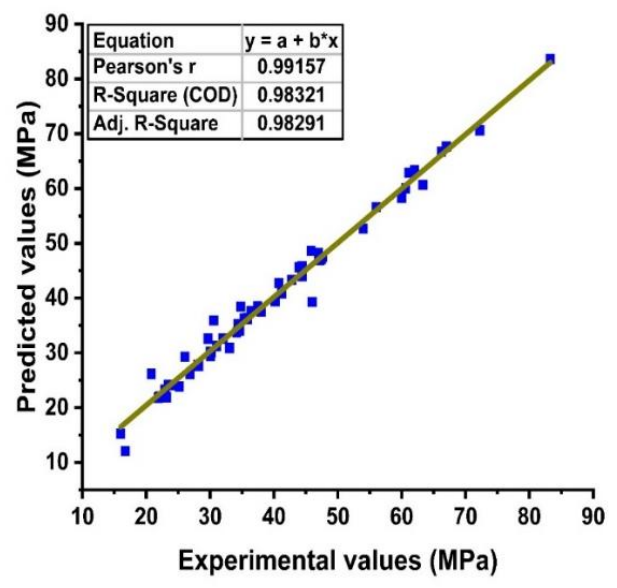

(b)

Figure 5. Cont. 


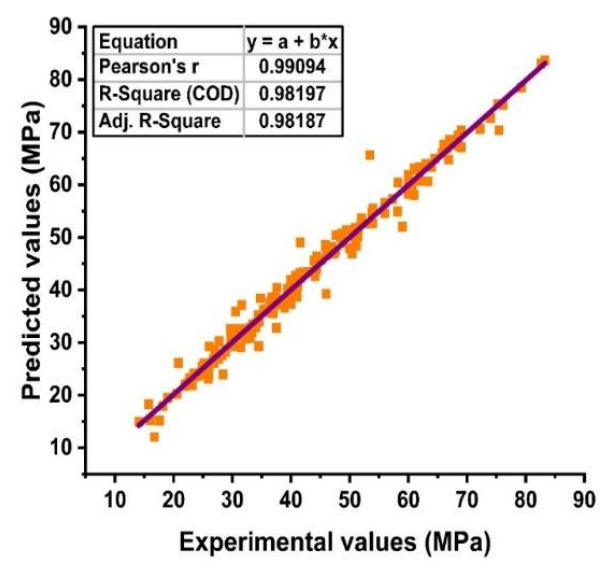

(c)

Figure 5. ANN (a) training, (b) validation, (c) testing.

\subsection{ANFIS}

Similarly, before training the data on ANFIS, parametric adjustments were made. These included total number of epochs and function used for the activation of ANFIS. The parametric adjustments for ANFIS are given in Table 5.

Table 5. Parametric adjustments for ANFIS.

\begin{tabular}{cc}
\hline Parameters & Description \\
\hline Training function & trimf \\
Epochs & 6 \\
Training completed at epoch & 2 \\
\hline
\end{tabular}

MATLAB is used for ANFIS. The correlation factor for ANFIS predicted CS $\left(\mathrm{R}^{2}=0.89\right)$ is also quite high. Figure 6 shows that the predicted results are quite close to the experimental values.

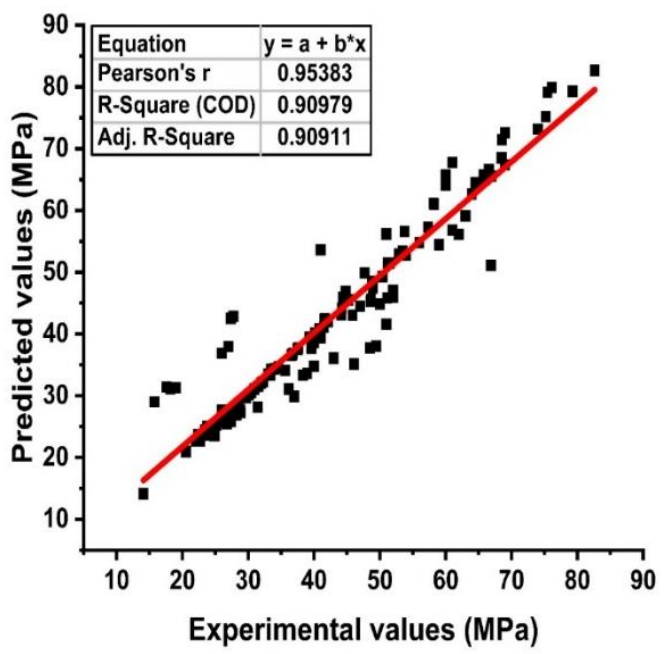

(a)

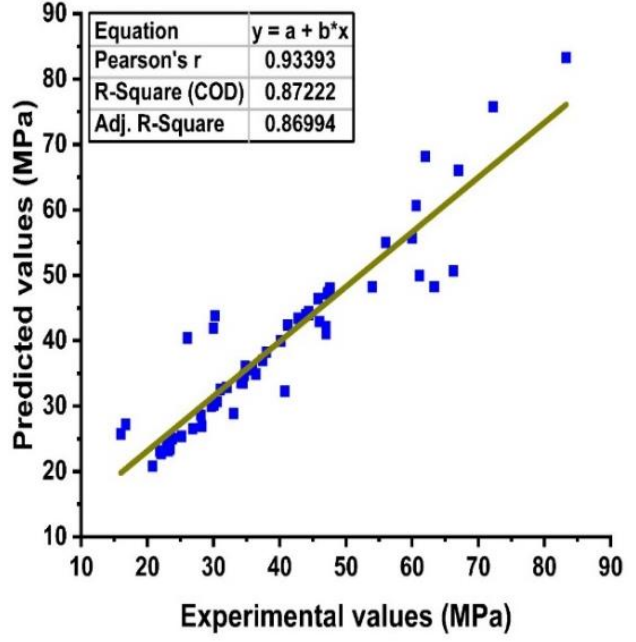

(b)

Figure 6. Cont. 


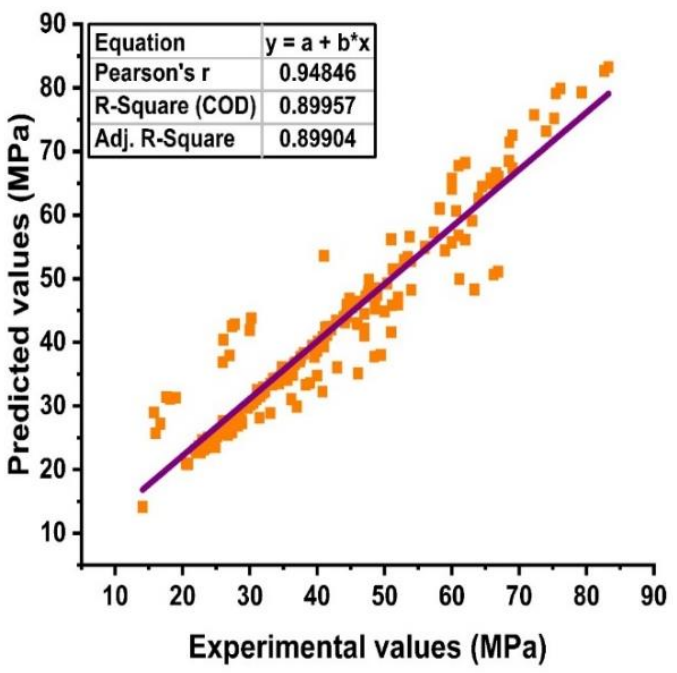

(c)

Figure 6. ANFIS (a) training, (b) validation, (c) testing.

Figure 7 shows the rules assigned to ANFIS for the optimum outcome.

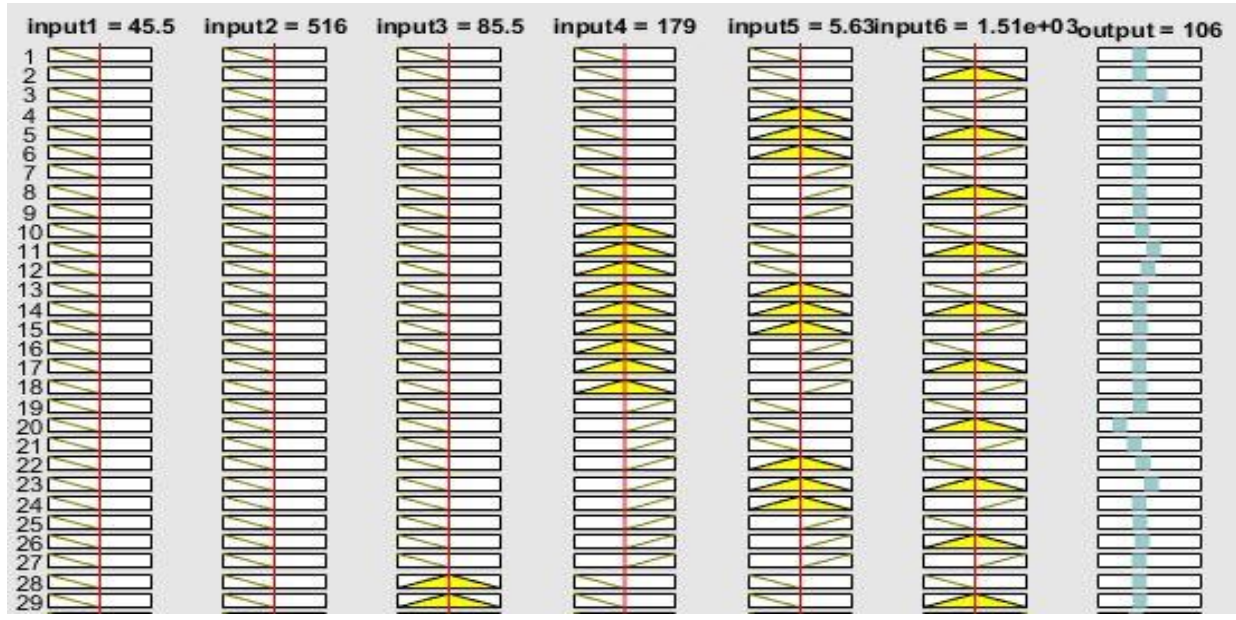

(a)
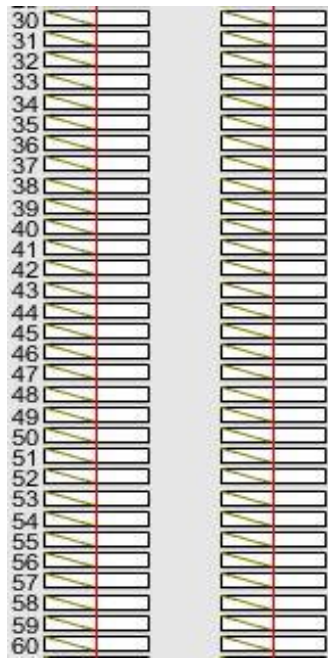

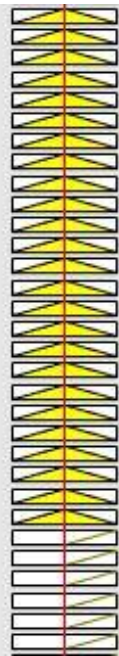

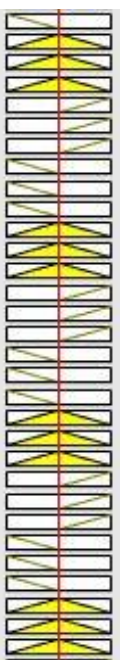
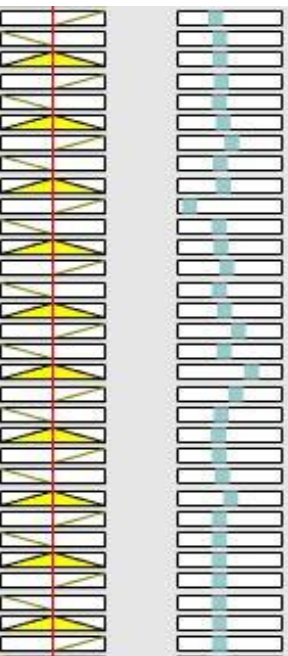

(b)

Figure 7. Cont. 

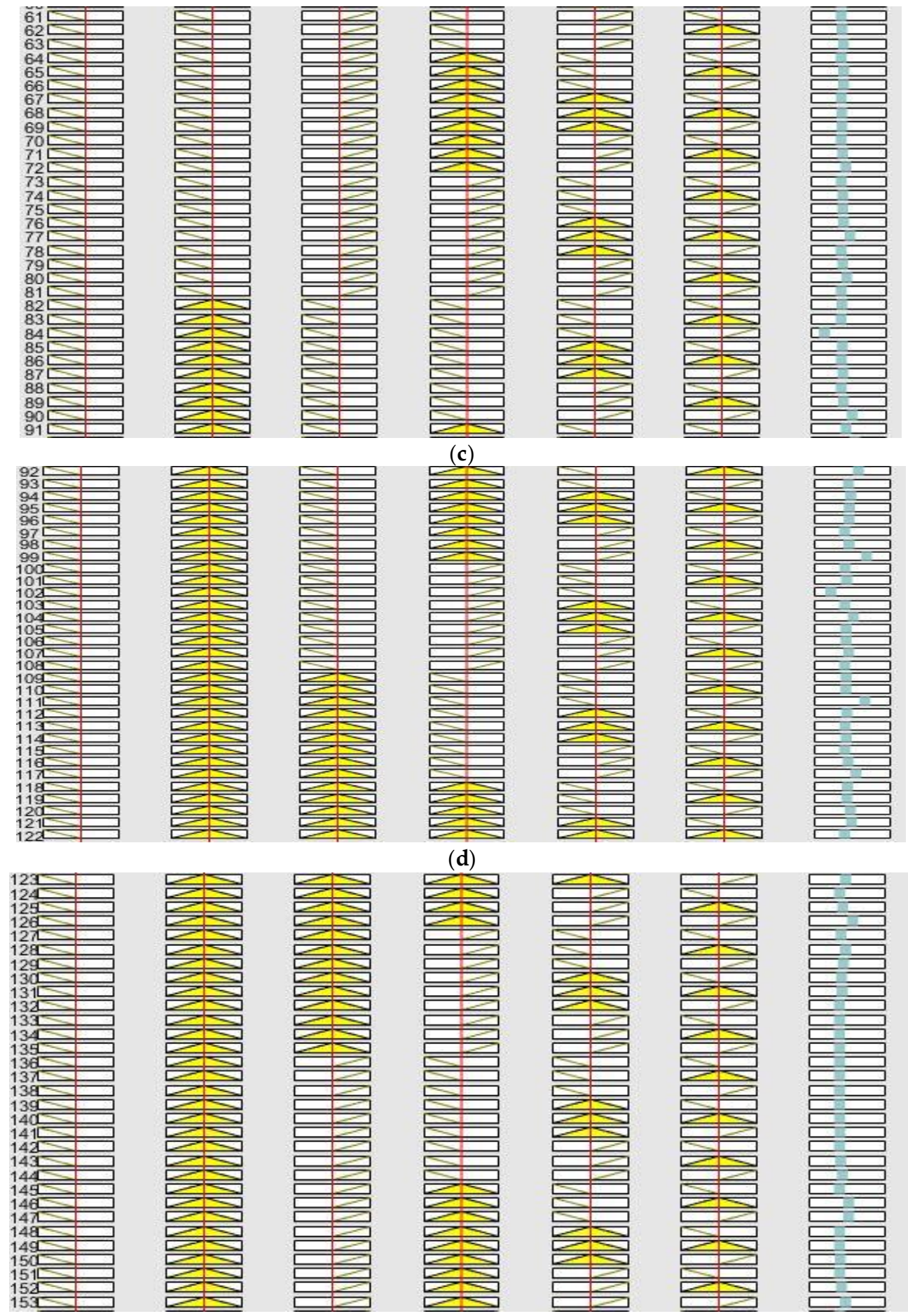

(e)

Figure 7. Cont. 

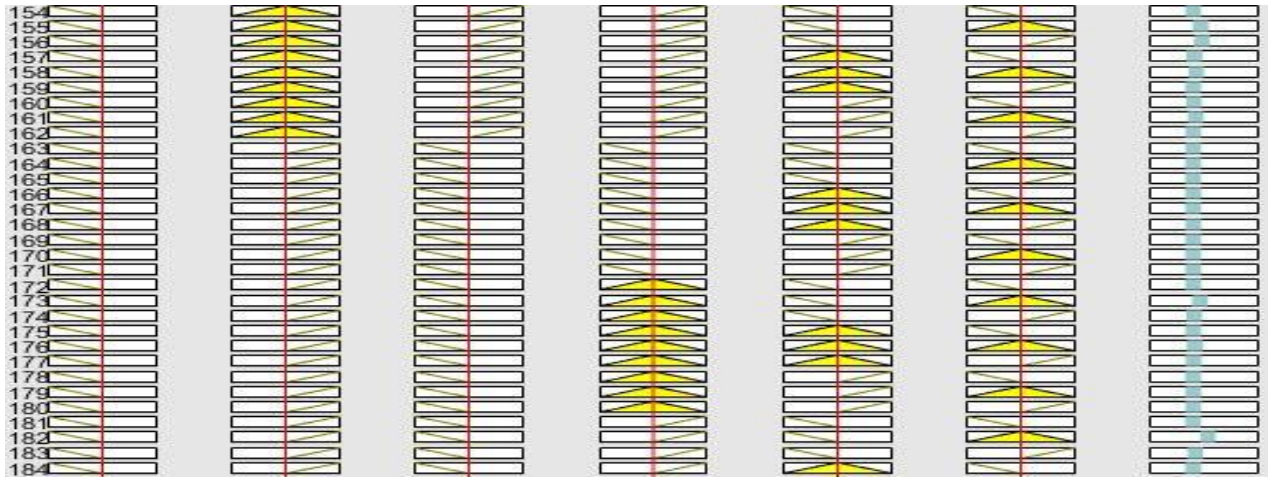

(f)
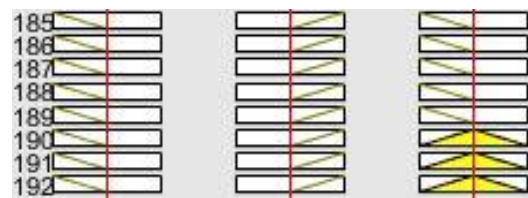
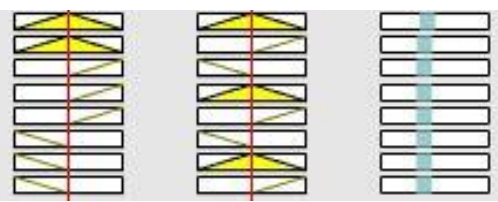

(g)

Figure 7. ANFIS modeling rules. (a) 1-29, (b) 30-60, (c) 61-91, (d) 92-122, (e) 123-153, (f) 154-184, (g) 185-192.

\subsection{MNLR}

The results predicted by MNLR were not close to the experimental results. The correlation factor for MNLR predicted CS $\left(R^{2}=0.70\right)$ confirms the same. The correlation factor for training and validation is 0.75 and 0.69 , respectively. The same can be confirmed by the dispersion of points in Figure 8 below.

\section{4. $L R 40$}

LR gave the results which were far away from the experimental results. A weak correlation $\left(R^{2}=0.63\right)$ existed between the experimental and predicted results. The correlation factor for LR training and LR validation is 0.64 and 0.62 , respectively. It can be seen in Figure 9 below that points are dispersed.

\subsection{Sensitivity and Parametric Analysis}

Different variables are used to find the CS of RBC. Sensitivity analysis (SA) is used to determine the relative contribution of these variables to the result. SA is carried out mathematically by using the following Equations:

$$
\begin{gathered}
N_{i}=f_{\max }\left(x_{i}\right)-f_{\min }\left(x_{i}\right) \\
S A=\frac{N_{i}}{\sum_{n}^{j=1} N_{j}}
\end{gathered}
$$

where $f_{\max }\left(x_{i}\right)$ is the maximum, and $f_{\min }\left(x_{i}\right)$ is the minimum output of the predictive models, respectively. Thus, $i$ represents the input domain and other input variables that are kept constant. It is obvious from the graphical representation (shown in Figure 10) that the contribution of different input variables on the CS of RBC is same as that in real life. 


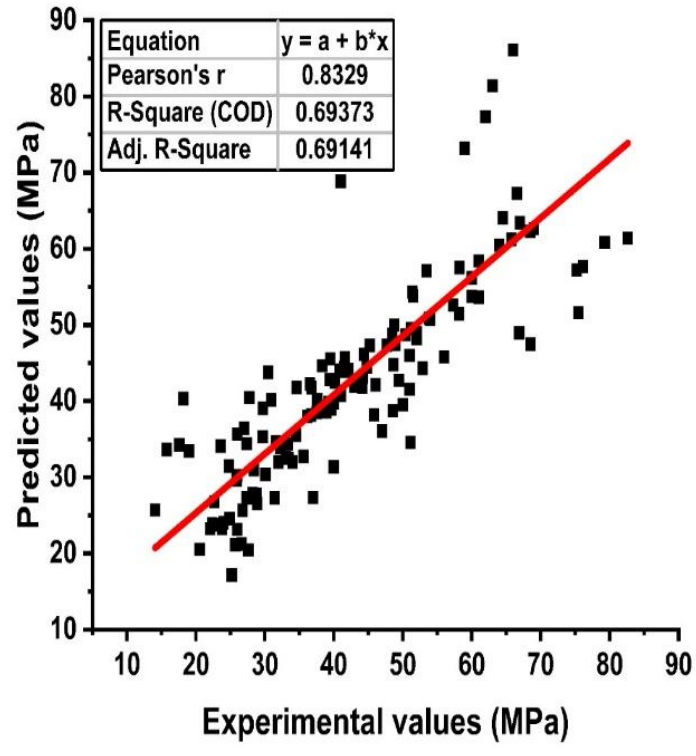

(a)

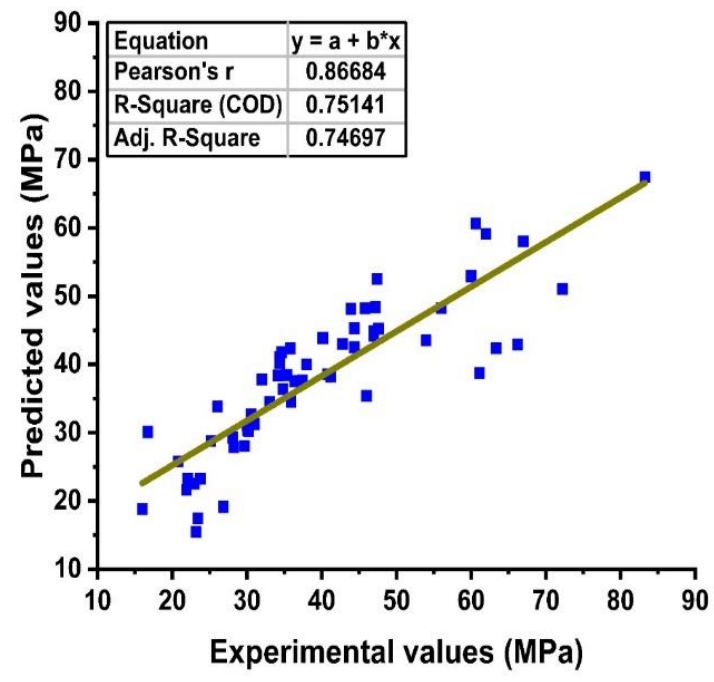

(b)

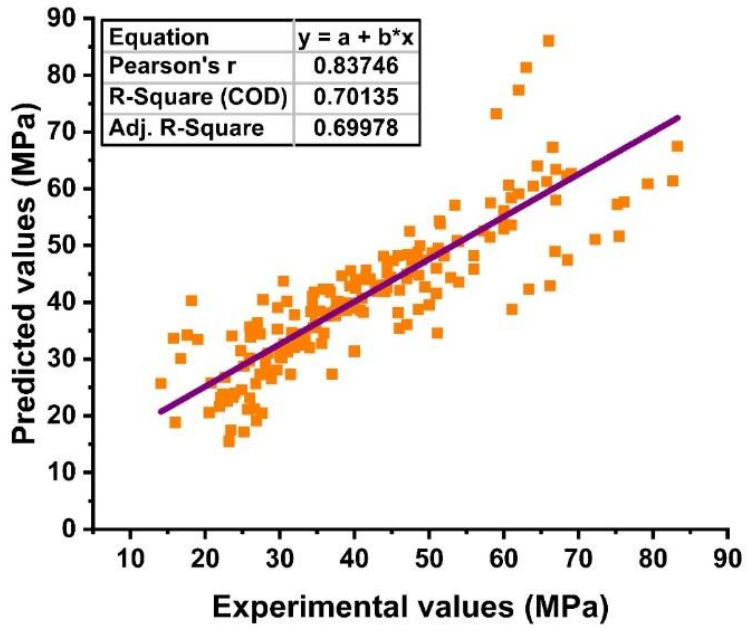

(c)

Figure 8. MNLR (a) training, (b), validation, (c) testing.

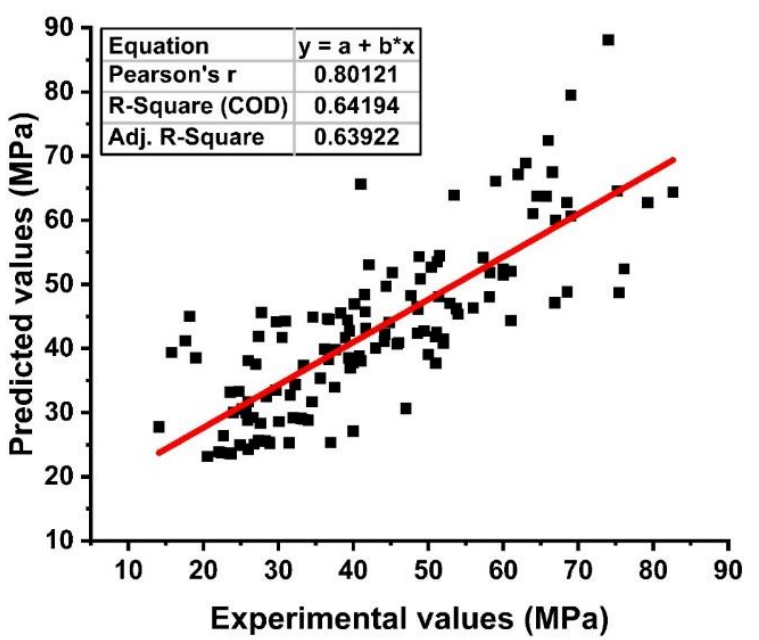

(a)

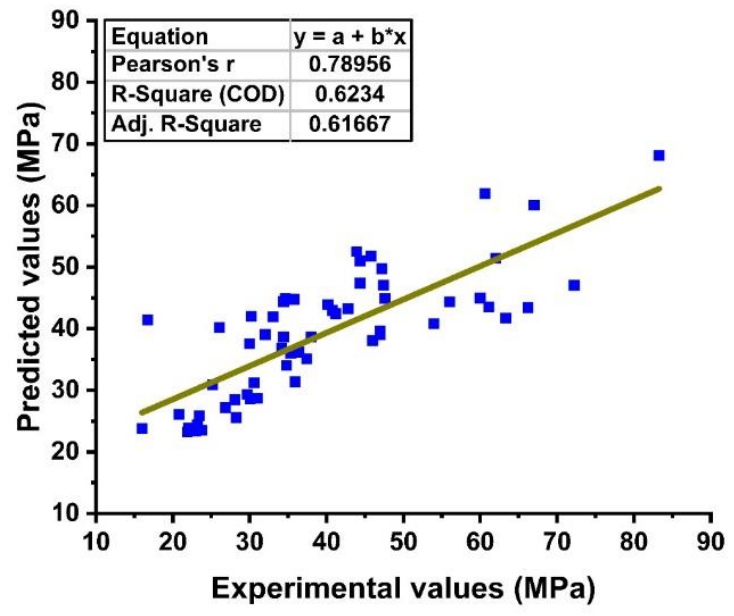

(b)

Figure 9. Cont. 


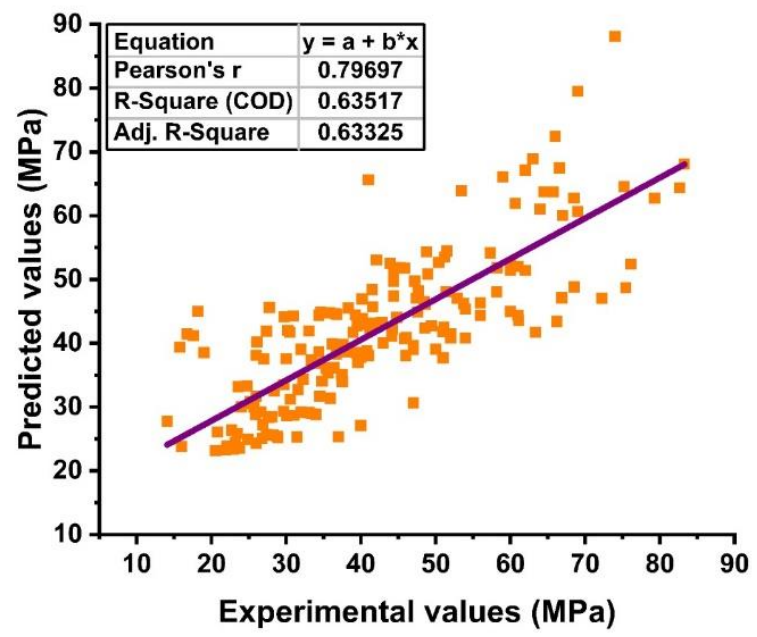

(c)

Figure 9. LR (a) training, (b) validation, (c) testing.

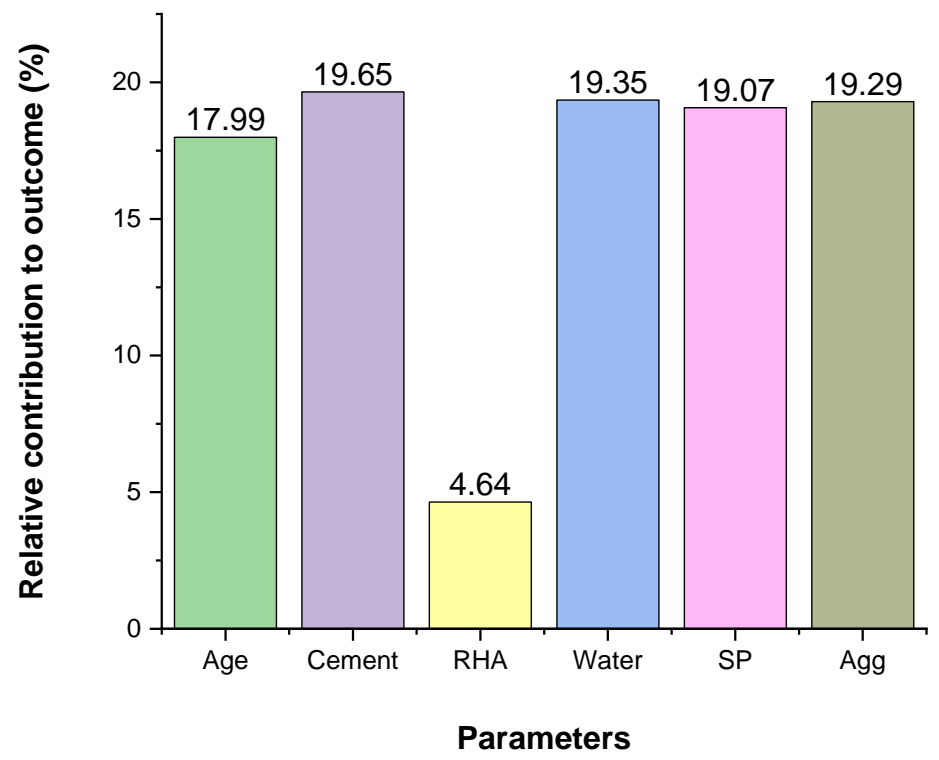

Figure 10. Contribution of inputs to the output.

Along with sensitivity analysis, a parametric analysis (PA) is also carried out. This helps in determining the influence of the input parameters on the output parameter. This shows the trend of CS when all the input variables are kept constant at their mean value except one input. The change in CS is recorded when one input variable is varied from its minimum value to its maximum value. All the results of PA are shown in Figure 11 below.

The sublots in front of each graph in Figure 11 represent the constant parameters of parametric analysis for each input. The literature used for obtaining experimental values includes [12,35-39]. It can be observed from the results that when water is increased from a certain limit, a reduction in CS occurs. This is also obvious from previous studies. De Sensale [39] conducted research in which a water to cement ratio $(\mathrm{w} / \mathrm{c})$ of 0.4 gave more CS than $\mathrm{w} / \mathrm{c}$ of 0.5. RHAP contributes towards the enhancement of strength, but when RHAP is increased by 30 percent, it results in decrease of compressive strength. This is due to the fact that, as discussed in Section 1, RHA contains 90 percent silica. By increasing the RHA percentage, the amount of silica is also increased. This silica remains unreacted by increment of RHA and results in reduced CS of RBC [37].

It can be seen from the above results that the regression models did not show satisfactory results as compared to the machine learning processes. This is due to certain 
limitations in regression models, such as pre-defined equations that cannot learn the relationship between input variables and the function properly. Whereas, machine learning has efficiently predicted the relationship between input and output variables. The machine learning techniques gave results closer to the experimental values.

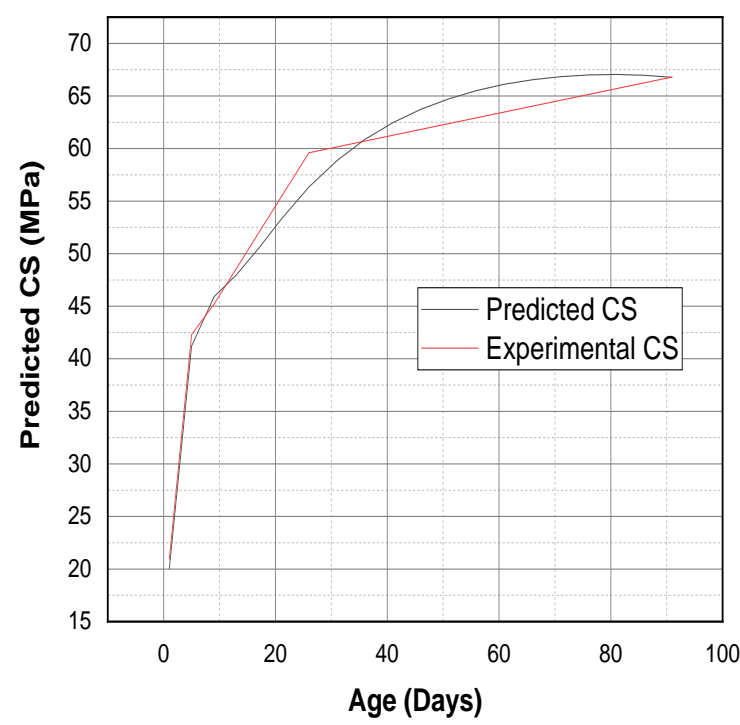

(a)

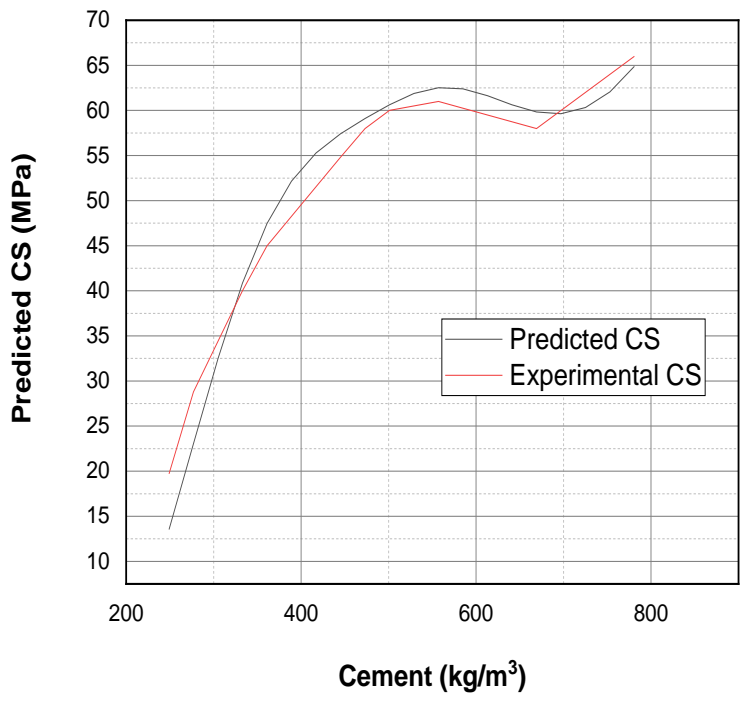

(b)

\begin{tabular}{ccccc}
\hline $\begin{array}{c}\text { Cement } \\
\left(\mathrm{kg} / \mathrm{m}^{3}\right)\end{array}$ & $\begin{array}{c}\text { RHA } \\
\left(\mathrm{kg} / \mathrm{m}^{3}\right)\end{array}$ & $\begin{array}{c}\mathrm{W} \\
\left(\mathrm{kg} / \mathrm{m}^{3}\right)\end{array}$ & $\begin{array}{c}\text { SP } \\
\left(\mathrm{kg} / \mathrm{m}^{3}\right)\end{array}$ & $\begin{array}{c}\mathrm{A} \\
\left(\mathrm{kg} / \mathrm{m}^{3}\right)\end{array}$ \\
\hline 409 & 60 & 192 & 3 & 1700 \\
\hline
\end{tabular}

\begin{tabular}{ccccc}
\hline $\begin{array}{c}\text { Age } \\
(\text { day })\end{array}$ & $\begin{array}{c}\text { RHA } \\
\left(\mathrm{kg} / \mathrm{m}^{3}\right)\end{array}$ & $\begin{array}{c}\text { W } \\
\left(\mathrm{kg} / \mathrm{m}^{3}\right)\end{array}$ & $\begin{array}{c}\text { SP } \\
\left(\mathrm{kg} / \mathrm{m}^{3}\right)\end{array}$ & $\begin{array}{c}\text { A } \\
\left(\mathrm{kg} / \mathrm{m}^{3}\right)\end{array}$ \\
\hline 35 & 24.9 & 192 & 3 & 1700 \\
\hline
\end{tabular}

Figure 11. Cont. 


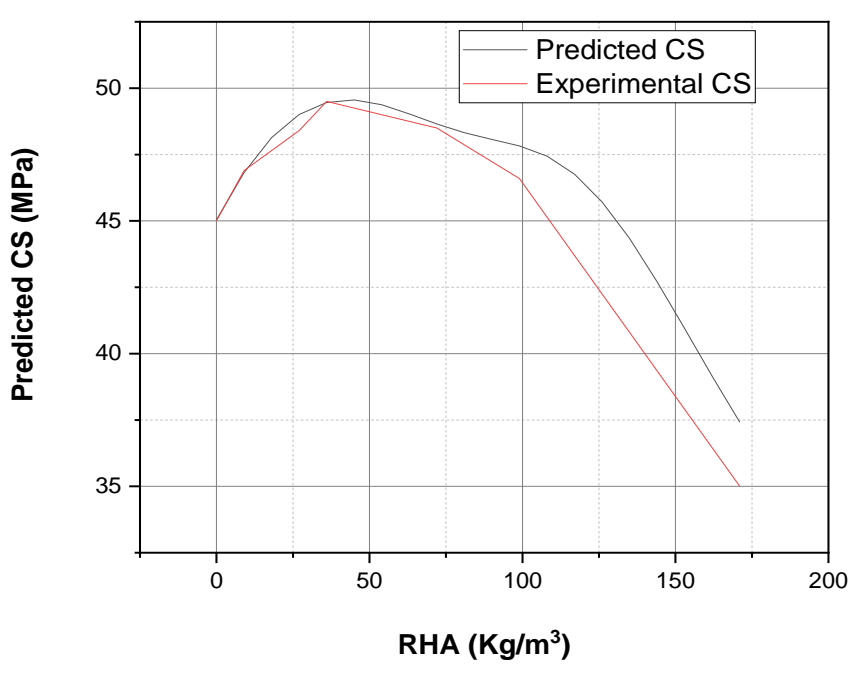

(c)

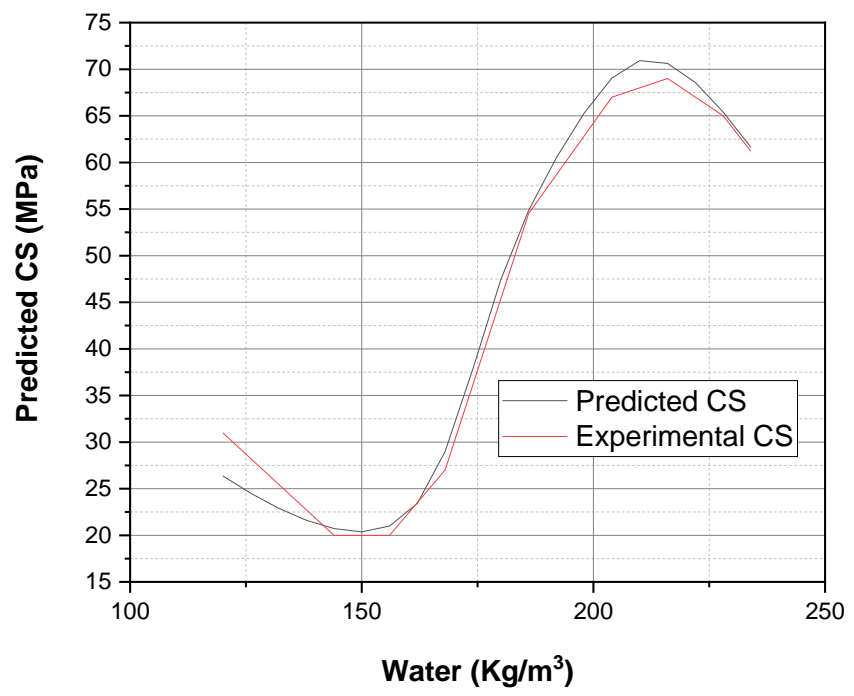

(d)

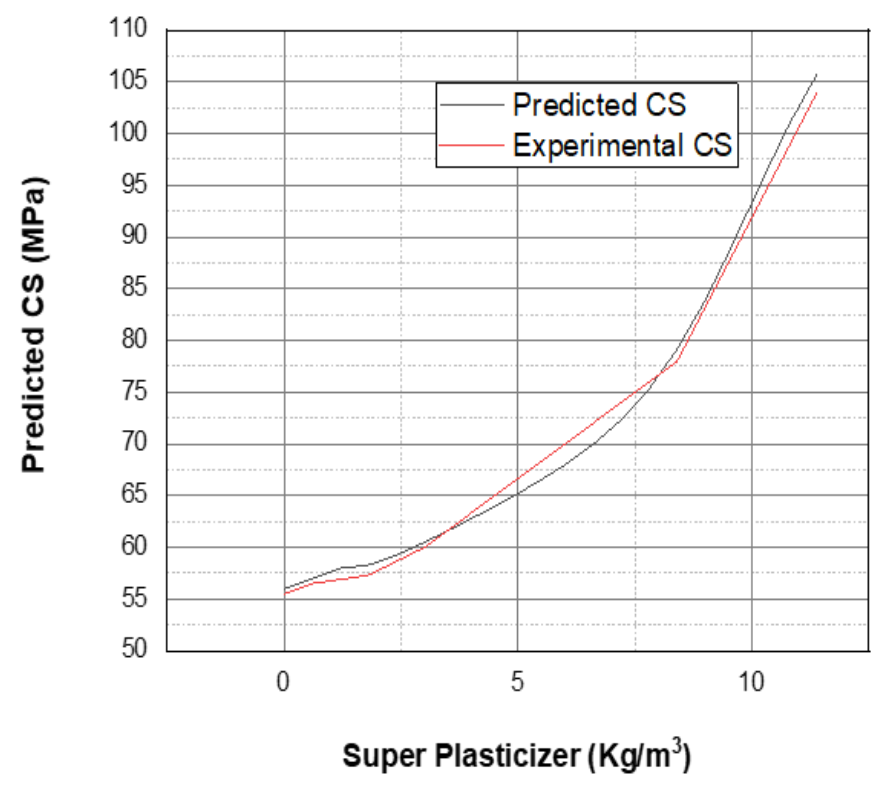

(e)

\begin{tabular}{ccccc}
\hline $\begin{array}{c}\text { Age } \\
(\text { day })\end{array}$ & $\begin{array}{c}\text { Cement } \\
\left(\mathrm{kg} / \mathrm{m}^{3}\right)\end{array}$ & $\begin{array}{c}\mathrm{W} \\
\left(\mathrm{kg} / \mathrm{m}^{3}\right)\end{array}$ & $\begin{array}{c}\mathrm{SP} \\
\left(\mathrm{kg} / \mathrm{m}^{3}\right)\end{array}$ & $\begin{array}{c}\mathrm{A} \\
\left(\mathrm{kg} / \mathrm{m}^{3}\right)\end{array}$ \\
\hline 35 & 409 & 192 & 3 & 1700 \\
\hline
\end{tabular}

\begin{tabular}{ccccc}
\hline $\begin{array}{c}\text { Age } \\
(\text { day })\end{array}$ & $\begin{array}{c}\text { Cement } \\
\left(\mathrm{kg} / \mathrm{m}^{3}\right)\end{array}$ & $\begin{array}{c}\text { RHA } \\
\left(\mathrm{kg} / \mathrm{m}^{3}\right)\end{array}$ & $\begin{array}{c}\mathrm{SP} \\
\left(\mathrm{kg} / \mathrm{m}^{3}\right)\end{array}$ & $\begin{array}{c}\mathrm{A} \\
\left(\mathrm{kg} / \mathrm{m}^{3}\right)\end{array}$ \\
\hline 35 & 409 & 60 & 3 & 1700 \\
\hline
\end{tabular}

\begin{tabular}{ccccc}
\hline $\begin{array}{c}\text { Age } \\
(\text { day })\end{array}$ & $\begin{array}{c}\text { Cement } \\
\left(\mathrm{kg} / \mathrm{m}^{3}\right)\end{array}$ & $\begin{array}{c}\text { RHA } \\
\left(\mathrm{kg} / \mathrm{m}^{3}\right)\end{array}$ & $\begin{array}{c}\text { W } \\
\left(\mathrm{kg} / \mathrm{m}^{3}\right)\end{array}$ & $\begin{array}{c}\text { A } \\
\left(\mathrm{kg} / \mathrm{m}^{3}\right)\end{array}$ \\
\hline 35 & 409 & 60 & 192 & 1700 \\
\hline
\end{tabular}

Figure 11. Cont. 


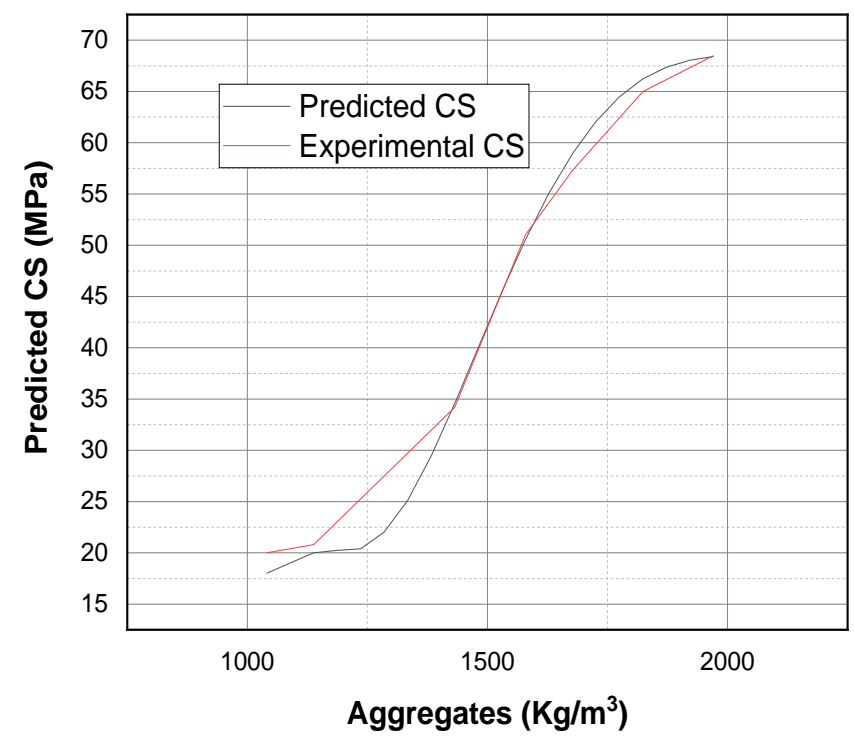

\begin{tabular}{ccccc}
\hline $\begin{array}{c}\text { Age } \\
(\text { day })\end{array}$ & $\begin{array}{c}\text { Cement } \\
\left(\mathrm{kg} / \mathrm{m}^{3}\right)\end{array}$ & $\begin{array}{c}\text { RHA } \\
\left(\mathrm{kg} / \mathrm{m}^{3}\right)\end{array}$ & $\begin{array}{c}\text { W } \\
\left(\mathrm{kg} / \mathrm{m}^{3}\right)\end{array}$ & $\begin{array}{c}\text { SP } \\
\left(\mathrm{kg} / \mathrm{m}^{3}\right)\end{array}$ \\
\hline 35 & 409 & 60 & 192 & 3 \\
\hline
\end{tabular}

(f)

Figure 11. Parametric analysis of inputs. (a) Age, (b) cement, (c) RHA, (d) water content, (e) superplasticizer, (f) aggregates.

\section{Conclusions}

Different models for prediction of CS of RBC are developed in this study. The models developed in this study are based on wide range of data which consist of different parameters demonstrated by experimental studies that are available in the literature. The models considered the most influential parameters on CS as inputs. The results obtained in this research are closer to the experimental research. The following conclusions can be drawn from the obtained results:

1. The PA has shown that the input parameters used in this research are effectively utilized by the model to predict the CS. Moreover, the statistical parameter $\mathrm{R}^{2}$ shows the accuracy of the data used for the training and validation of different models.

2. The $R^{2}$ for the predicted strengths of ANN, ANFIS, MNLR, and LR is $0.98,0.89,0.70$, and 0.63 , respectively.

3. It is evident by the comparison of ANN and ANFIS with the regression models that both ANN and ANFIS have a high command on prediction of CS of RBC. Therefore, they are suitable for the predesign of RBC.

4. The proposed models can provide the basis for using RBC in different structures rather than discarding it.

Concrete containing RHA has a great potential to replace OPC concrete. It is recommended that extensive research be carried out by including more parameters. These parameters should include temperature, corrosion, and resistance to chlorine and acid attacks. Other advanced programming techniques such as an M5P tree and gene expression programming can be used to make further predictions.

Author Contributions: A.I.: Conceptualization, data analysis, writing original draft and preparation, N.B.K.: Formal analysis and modelling, S.K.-u.-R.: Supervision, review and editing, M.F.J.: Investigation and review, F.A.: Methodology, review and editing, R.A.: Software, validation check and supervision, H.A.: Review, editing and supervision, A.M.: Validation, review, and supervision. All authors have read and agreed to the published version of the manuscript.

Funding: This research received no external funding.

Data Availability Statement: Not applicable.

Acknowledgments: Amir Mosavi would like to thank Alexander von Humboldt Foundation. 
Conflicts of Interest: The authors declare no conflict of interest.

\section{Abbreviations}

\begin{tabular}{|c|c|}
\hline Nomenclature & Definition \\
\hline AGG & Amount of aggregates \\
\hline AI & Artificial intelligence \\
\hline ANFIS & Adaptive neuro-fuzzy inference system \\
\hline ANN & Artificial neural network \\
\hline CA & Curing age \\
\hline CCA & Corn cob ash \\
\hline CS & Compressive strength \\
\hline FA & Fly ash \\
\hline FFBP & Feed forward back propagation \\
\hline GGBFS & Ground granulated blast furnace slag \\
\hline GWP & Global warming potential \\
\hline LR & Linear regression \\
\hline MLP & Multi layer perceptron \\
\hline MNLR & Multiple nonlinear regression \\
\hline $\mathrm{OPC}$ & Ordinary Portland cement \\
\hline OPCP & Amount of OPC \\
\hline $\mathrm{RBC}$ & RHA blended concrete \\
\hline $\mathrm{RH}$ & Rice Husks \\
\hline RHA & Rice husk ash \\
\hline RHAP & Amount of RHA \\
\hline SCBA & Sugarcane baggase ash \\
\hline SCM & Secondary cementitious material \\
\hline SLP & Single layer perceptron \\
\hline SP & Superplasticizer \\
\hline W & Water used \\
\hline
\end{tabular}

\section{Appendix A}

Table A1. Compressive strength (CS) (MPa) results obtained through different models.

\begin{tabular}{ccccc}
\hline Experimental & ANN Prediction & ANFIS Prediction & LR Prediction & MNLR \\
\hline 18.16 & 17.91 & 31.12 & 45.00 & 40.31 \\
16.72 & 12.06 & 27.21 & 41.43 & 30.10 \\
17.6 & 15.19 & 31.43 & 41.21 & 34.24 \\
15.76 & 18.26 & 29.00 & 39.39 & 33.65 \\
27.76 & 30.28 & 42.86 & 45.59 & 40.46 \\
30.24 & 30.12 & 43.81 & 42.02 & 30.25 \\
27.36 & 27.30 & 42.54 & 41.88 & 34.41 \\
26.08 & 29.29 & 40.42 & 40.21 & 33.86 \\
38.32 & 37.24 & 33.33 & 45.51 & 44.64 \\
33.04 & 30.89 & 28.89 & 41.93 & 34.44 \\
38.96 & 36.67 & 33.62 & 41.71 & 38.58 \\
36.16 & 35.72 & 31.05 & 39.89 & 37.99 \\
14.08 & 14.95 & 14.11 & 27.75 & 25.72 \\
48.64 & 50.77 & 45.60 & 46.09 & 44.79 \\
51.12 & 49.99 & 45.85 & 42.52 & 34.58 \\
48.56 & 50.10 & 45.25 & 42.38 & 38.75 \\
45.84 & 48.30 & 43.04 & 40.71 & 38.20 \\
48.48 & 49.97 & 37.76 & 46.52 & 48.79 \\
40.8 & 42.73 & 32.25 & 42.95 & 38.59 \\
49.44 & 51.43 & 38.02 & 42.72 & 42.73 \\
24 & 23.64 & 24.81 & 30.02 & 24.01 \\
\hline
\end{tabular}


Table A1. Cont.

\begin{tabular}{|c|c|c|c|c|}
\hline Experimental & ANN Prediction & ANFIS Prediction & LR Prediction & MNLR \\
\hline 25.2 & 23.86 & 25.39 & 30.85 & 28.80 \\
\hline 26 & 23.83 & 27.60 & 31.67 & 30.22 \\
\hline 28.4 & 23.95 & 28.54 & 32.50 & 31.01 \\
\hline 24.8 & 24.43 & 25.31 & 33.33 & 31.46 \\
\hline 22.08 & 22.04 & 22.70 & 23.90 & 23.28 \\
\hline 23.76 & 24.07 & 25.01 & 23.52 & 23.27 \\
\hline 20.56 & 20.25 & 20.97 & 23.16 & 20.56 \\
\hline 46.08 & 46.67 & 35.13 & 40.90 & 42.14 \\
\hline 66.88 & 64.77 & 51.09 & 47.10 & 48.94 \\
\hline 25.92 & 23.20 & 25.88 & 28.85 & 29.66 \\
\hline 61.12 & 62.83 & 49.95 & 43.53 & 38.73 \\
\hline 66.24 & 66.69 & 50.67 & 43.39 & 42.90 \\
\hline 63.36 & 60.64 & 48.28 & 41.73 & 42.35 \\
\hline 28.24 & 27.61 & 26.93 & 25.55 & 27.87 \\
\hline 28.88 & 28.21 & 27.26 & 25.17 & 26.58 \\
\hline 58.24 & 60.42 & 60.99 & 51.83 & 57.53 \\
\hline 47.68 & 50.46 & 49.89 & 48.25 & 47.32 \\
\hline 58.16 & 54.92 & 61.09 & 48.03 & 51.46 \\
\hline 35.6 & 36.04 & 34.11 & 35.33 & 32.74 \\
\hline 36.4 & 37.66 & 34.88 & 36.16 & 37.53 \\
\hline 39.6 & 38.16 & 37.72 & 36.98 & 38.95 \\
\hline 40 & 37.39 & 38.61 & 37.81 & 39.75 \\
\hline 34.4 & 35.20 & 33.55 & 38.64 & 40.19 \\
\hline 29.68 & 32.60 & 29.98 & 29.33 & 28.05 \\
\hline 33.44 & 33.46 & 34.23 & 28.96 & 32.49 \\
\hline 30.08 & 29.41 & 30.17 & 28.59 & 30.37 \\
\hline 53.76 & 54.72 & 56.59 & 46.21 & 50.87 \\
\hline 76.16 & 75.21 & 79.90 & 52.41 & 57.68 \\
\hline 68.56 & 67.37 & 71.43 & 48.84 & 47.47 \\
\hline 75.44 & 70.38 & 79.14 & 48.70 & 51.63 \\
\hline 32.24 & 30.73 & 32.25 & 34.34 & 33.92 \\
\hline 37.52 & 32.79 & 37.51 & 33.94 & 38.46 \\
\hline 72.24 & 70.61 & 75.79 & 47.04 & 51.08 \\
\hline 41.2 & 40.88 & 42.37 & 42.41 & 38.23 \\
\hline 42.8 & 43.35 & 43.43 & 43.24 & 43.02 \\
\hline 44.8 & 45.59 & 46.88 & 44.06 & 44.44 \\
\hline 47.6 & 47.49 & 48.07 & 44.89 & 45.24 \\
\hline 41.6 & 49.06 & 42.34 & 45.72 & 45.68 \\
\hline 66.56 & 66.98 & 66.55 & 67.50 & 67.30 \\
\hline 53.44 & 65.68 & 53.44 & 63.93 & 57.09 \\
\hline 65.76 & 66.02 & 65.76 & 63.71 & 61.23 \\
\hline 60.64 & 60.01 & 60.65 & 61.89 & 60.64 \\
\hline 34.64 & 34.06 & 34.65 & 44.88 & 41.78 \\
\hline 36.8 & 36.36 & 36.85 & 44.51 & 41.77 \\
\hline 29.76 & 30.66 & 29.74 & 44.14 & 39.06 \\
\hline 44.4 & 45.77 & 44.01 & 51.01 & 42.51 \\
\hline 45.2 & 45.74 & 45.49 & 51.83 & 47.30 \\
\hline 50.4 & 46.92 & 49.25 & 52.66 & 48.72 \\
\hline 51.2 & 48.40 & 51.52 & 53.49 & 49.52 \\
\hline 48.8 & 49.83 & 48.52 & 54.31 & 49.96 \\
\hline 47.2 & 46.94 & 47.20 & 49.75 & 48.38 \\
\hline 83.28 & 83.60 & 83.29 & 68.09 & 67.45 \\
\hline 75.2 & 75.35 & 75.20 & 64.52 & 57.24 \\
\hline 82.64 & 83.02 & 82.64 & 64.38 & 61.40 \\
\hline 79.28 & 78.48 & 79.27 & 62.71 & 60.85 \\
\hline 39.5 & 39.69 & 39.50 & 42.75 & 45.55 \\
\hline 30.5 & 30.47 & 30.50 & 41.75 & 43.76 \\
\hline
\end{tabular}


Table A1. Cont.

\begin{tabular}{|c|c|c|c|c|}
\hline Experimental & ANN Prediction & ANFIS Prediction & LR Prediction & MNLR \\
\hline 29.7 & 29.35 & 29.70 & 33.47 & 35.31 \\
\hline 23.6 & 23.61 & 23.60 & 33.19 & 34.09 \\
\hline 22.7 & 23.21 & 22.70 & 26.39 & 26.79 \\
\hline 20.8 & 26.18 & 20.80 & 26.05 & 25.81 \\
\hline 51.4 & 50.15 & 51.40 & 48.06 & 54.28 \\
\hline 47.4 & 47.08 & 47.40 & 47.06 & 52.50 \\
\hline 40.8 & 40.61 & 40.80 & 38.78 & 44.04 \\
\hline 39.4 & 40.25 & 39.40 & 38.50 & 42.82 \\
\hline 34.5 & 29.33 & 34.50 & 31.70 & 35.53 \\
\hline 35.9 & 36.13 & 35.90 & 31.36 & 34.54 \\
\hline 64.5 & 64.94 & 64.50 & 63.74 & 64.05 \\
\hline 68.5 & 69.42 & 68.50 & 62.74 & 62.27 \\
\hline 51.5 & 51.89 & 51.50 & 54.46 & 53.81 \\
\hline 57.3 & 57.27 & 57.30 & 54.17 & 52.59 \\
\hline 44.4 & 43.98 & 44.40 & 47.38 & 45.30 \\
\hline 52.9 & 52.55 & 52.90 & 47.04 & 44.31 \\
\hline 25.2 & 26.10 & 25.23 & 30.56 & 17.15 \\
\hline 25.68 & 25.92 & 25.73 & 30.00 & 21.15 \\
\hline 26.64 & 26.24 & 26.88 & 29.25 & 21.23 \\
\hline 27.6 & 26.90 & 27.46 & 28.31 & 20.45 \\
\hline 26.88 & 26.18 & 26.53 & 27.20 & 19.16 \\
\hline 23.44 & 24.15 & 23.45 & 25.90 & 17.47 \\
\hline 23.2 & 21.95 & 23.16 & 24.42 & 15.46 \\
\hline 33.36 & 31.93 & 33.37 & 37.39 & 34.36 \\
\hline 34.16 & 33.71 & 33.61 & 36.82 & 38.37 \\
\hline 35.36 & 36.30 & 35.56 & 36.07 & 38.45 \\
\hline 37.44 & 38.46 & 36.98 & 35.14 & 37.67 \\
\hline 34.8 & 38.45 & 36.07 & 34.03 & 36.38 \\
\hline 31.6 & 37.15 & 31.50 & 32.73 & 34.69 \\
\hline 30.56 & 35.91 & 30.67 & 31.25 & 32.68 \\
\hline 39.28 & 37.51 & 39.44 & 44.47 & 39.86 \\
\hline 40.16 & 39.41 & 39.95 & 43.90 & 43.86 \\
\hline 41.68 & 42.31 & 42.42 & 43.15 & 43.94 \\
\hline 44.24 & 43.81 & 44.16 & 42.22 & 43.16 \\
\hline 44.16 & 42.63 & 43.10 & 41.10 & 41.87 \\
\hline 37.6 & 40.41 & 37.76 & 39.81 & 40.18 \\
\hline 36.72 & 38.56 & 36.63 & 38.33 & 38.17 \\
\hline 42.08 & 43.41 & 41.98 & 53.07 & 44.13 \\
\hline 43.92 & 45.62 & 43.95 & 52.50 & 48.14 \\
\hline 45.84 & 48.62 & 46.40 & 51.75 & 48.21 \\
\hline 48.96 & 48.95 & 47.45 & 50.82 & 47.44 \\
\hline 44.4 & 46.41 & 45.86 & 49.70 & 46.15 \\
\hline 41.52 & 43.25 & 41.14 & 48.40 & 44.46 \\
\hline 40.16 & 40.79 & 40.18 & 46.92 & 42.45 \\
\hline 41 & 40.43 & 53.59 & 65.61 & 68.86 \\
\hline 30 & 30.26 & 41.92 & 37.55 & 31.04 \\
\hline 27 & 28.62 & 37.95 & 37.54 & 36.42 \\
\hline 26 & 26.13 & 36.87 & 38.13 & 35.68 \\
\hline 19 & 19.53 & 31.29 & 38.54 & 33.46 \\
\hline 16 & 15.26 & 25.75 & 23.81 & 18.84 \\
\hline 59 & 52.03 & 54.44 & 66.11 & 73.19 \\
\hline 46 & 39.32 & 42.89 & 38.05 & 35.37 \\
\hline 41 & 38.71 & 39.35 & 38.05 & 40.75 \\
\hline 38 & 37.54 & 38.27 & 38.64 & 40.02 \\
\hline 32 & 32.63 & 32.88 & 39.04 & 37.80 \\
\hline 26 & 25.29 & 27.13 & 24.32 & 23.18 \\
\hline 62 & 60.76 & 56.13 & 67.12 & 77.34 \\
\hline 50 & 47.89 & 44.83 & 39.06 & 39.53 \\
\hline 47 & 48.19 & 42.14 & 39.06 & 44.90 \\
\hline
\end{tabular}


Table A1. Cont.

\begin{tabular}{|c|c|c|c|c|}
\hline Experimental & ANN Prediction & ANFIS Prediction & LR Prediction & MNLR \\
\hline 47 & 47.53 & 41.06 & 39.65 & 44.17 \\
\hline 43 & 43.50 & 36.06 & 40.05 & 41.95 \\
\hline 37 & 35.53 & 29.91 & 25.33 & 27.33 \\
\hline 63 & 64.01 & 59.09 & 68.89 & 81.37 \\
\hline 54 & 52.69 & 48.22 & 40.83 & 43.56 \\
\hline 52 & 53.58 & 47.03 & 40.83 & 48.93 \\
\hline 52 & 52.95 & 45.93 & 41.42 & 48.20 \\
\hline 51 & 48.99 & 41.63 & 41.82 & 45.98 \\
\hline 40 & 41.96 & 34.77 & 27.10 & 31.36 \\
\hline 66 & 67.67 & 65.01 & 72.43 & 86.08 \\
\hline 56 & 56.63 & 55.01 & 44.37 & 48.26 \\
\hline 61 & 58.11 & 56.80 & 44.37 & 53.64 \\
\hline 60 & 58.28 & 55.69 & 44.96 & 52.90 \\
\hline 54 & 55.56 & 52.77 & 45.36 & 50.68 \\
\hline 47 & 47.06 & 44.48 & 30.64 & 36.06 \\
\hline 69 & 70.31 & 72.59 & 79.51 & 91.57 \\
\hline 60 & 61.89 & 64.09 & 51.45 & 53.75 \\
\hline 62 & 63.30 & 68.19 & 51.45 & 59.13 \\
\hline 61 & 63.18 & 67.77 & 52.04 & 58.39 \\
\hline 60 & 60.58 & 65.74 & 52.44 & 56.17 \\
\hline 51 & 51.74 & 56.18 & 37.72 & 41.55 \\
\hline 74 & 72.72 & 73.15 & 88.11 & 95.85 \\
\hline 67 & 67.64 & 66.03 & 60.05 & 58.03 \\
\hline 67 & 68.51 & 65.54 & 60.04 & 63.41 \\
\hline 69 & 67.15 & 67.40 & 60.63 & 62.67 \\
\hline 64 & 63.34 & 62.65 & 61.04 & 60.45 \\
\hline 56 & 54.59 & 54.77 & 46.32 & 45.83 \\
\hline 22.08 & 22.04 & 22.70 & 23.90 & 23.28 \\
\hline 22.4 & 22.26 & 23.66 & 23.78 & 23.84 \\
\hline 23.44 & 23.49 & 24.42 & 23.65 & 23.75 \\
\hline 23.76 & 24.07 & 25.01 & 23.52 & 23.27 \\
\hline 22.96 & 23.29 & 24.63 & 23.40 & 22.55 \\
\hline 21.92 & 21.81 & 23.13 & 23.28 & 21.64 \\
\hline 20.56 & 20.25 & 20.97 & 23.16 & 20.56 \\
\hline 27.36 & 27.33 & 25.81 & 25.67 & 27.31 \\
\hline 28.24 & 27.61 & 26.93 & 25.55 & 27.87 \\
\hline 28.8 & 28.72 & 27.69 & 25.42 & 27.78 \\
\hline 31.44 & 29.08 & 28.12 & 25.29 & 27.30 \\
\hline 28.88 & 28.21 & 27.26 & 25.17 & 26.58 \\
\hline 26.8 & 26.79 & 25.47 & 25.05 & 25.67 \\
\hline 24.88 & 25.41 & 23.52 & 24.93 & 24.59 \\
\hline 32 & 32.36 & 32.04 & 29.21 & 32.01 \\
\hline 33.04 & 32.86 & 33.46 & 29.09 & 32.58 \\
\hline 33.44 & 33.46 & 34.23 & 28.96 & 32.49 \\
\hline 34 & 32.88 & 34.33 & 28.83 & 32.00 \\
\hline 31.04 & 31.26 & 32.52 & 28.71 & 31.28 \\
\hline 30.08 & 29.41 & 30.17 & 28.59 & 30.37 \\
\hline 28.08 & 27.85 & 28.61 & 28.47 & 29.29 \\
\hline 34.64 & 34.06 & 34.65 & 44.88 & 41.78 \\
\hline 35.84 & 36.36 & 35.81 & 44.76 & 42.35 \\
\hline 36.56 & 37.27 & 36.54 & 44.64 & 42.26 \\
\hline 36.8 & 36.36 & 36.85 & 44.51 & 41.77 \\
\hline 34.4 & 34.58 & 34.26 & 44.39 & 41.05 \\
\hline 30.96 & 32.60 & 31.06 & 44.26 & 40.14 \\
\hline 29.76 & 30.66 & 29.74 & 44.14 & 39.06 \\
\hline
\end{tabular}

\section{References}

1. Chen, C.; Habert, G.; Bouzidi, Y.; Jullien, A. Environmental impact of cement production: Detail of the different processes and cement plant variability evaluation. J. Clean. Prod. 2010, 18, 478-485. [CrossRef] 
2. Farooq, F.; Ahmed, W.; Akbar, A.; Aslam, F.; Alyousef, R. Predictive modeling for sustainable high-performance concrete from industrial wastes: A comparison and optimization of models using ensemble learners. J. Clean. Prod. 2021, 292, 126032. [CrossRef]

3. Mahlia, T.M.I. Emissions from electricity generation in Malaysia. Renew. Energy 2002, 27, 293-300. [CrossRef]

4. Akbar, A.; Farooq, F.; Shafique, M.; Aslam, F.; Alyousef, R.; Alabduljabbar, H. Sugarcane bagasse ash-based engineered geopolymer mortar incorporating propylene fibers. J. Build. Eng. 2021, 33, 101492. [CrossRef]

5. Mehta, A.; Siddique, R. An overview of geopolymers derived from industrial by-products. Constr. Build. Mater. 2016, 127, 183-198. [CrossRef]

6. Tosti, L.; van Zomeren, A.; Pels, J.R.; Damgaard, A.; Comans, R.N.J. Life cycle assessment of the reuse of fly ash from biomass combustion as secondary cementitious material in cement products. J. Clean. Prod. 2020, 245, 118937. [CrossRef]

7. Zain, M.F.M.; Islam, M.N.; Mahmud, F.; Jamil, M. Production of rice husk ash for use in concrete as a supplementary cementitious material. Constr. Build. Mater. 2011, 25, 798-805. [CrossRef]

8. Adesanya, D.A.; Raheem, A.A. Development of corn cob ash blended cement. Constr. Build. Mater. 2009, 23, 347-352. [CrossRef]

9. Crossin, E. The greenhouse gas implications of using ground granulated blast furnace slag as a cement substitute. J. Clean. Prod. 2015, 95, 101-108. [CrossRef]

10. Khan, K.; Ullah, M.F.; Shahzada, K.; Amin, M.N.; Bibi, T.; Wahab, N.; Aljaafari, A. Effective use of micro-silica extracted from rice husk ash for the production of high-performance and sustainable cement mortar. Constr. Build. Mater. 2020, $258,119589$. [CrossRef]

11. Parveen, S.; Pham, T.M. Enhanced properties of high-silica rice husk ash-based geopolymer paste by incorporating basalt fibers. Constr. Build. Mater. 2020, 245, 118422. [CrossRef]

12. Ameri, F.; Shoaei, P.; Bahrami, N.; Vaezi, M.; Ozbakkaloglu, T. Optimum rice husk ash content and bacterial concentration in self-compacting concrete. Constr. Build. Mater. 2019, 222, 796-813. [CrossRef]

13. Chao-Lung, H.; Anh-Tuan, B.L.; Chun-Tsun, C. Effect of rice husk ash on the strength and durability characteristics of concrete. Constr. Build. Mater. 2011, 25, 3768-3772. [CrossRef]

14. Chindaprasirt, P.; Kanchanda, P.; Sathonsaowaphak, A.; Cao, H.T. Sulfate resistance of blended cements containing fly ash and rice husk ash. Constr. Build. Mater. 2007, 21, 1356-1361. [CrossRef]

15. Thomas, B.S. Green concrete partially comprised of rice husk ash as a supplementary cementitious material-A comprehensive review. Renew. Sustain. Energy Rev. 2018, 82, 3913-3923. [CrossRef]

16. Rattanachu, P.; Toolkasikorn, P.; Tangchirapat, W.; Chindaprasirt, P.; Jaturapitakkul, C. Performance of recycled aggregate concrete with rice husk ash as cement binder. Cem. Concr. Compos. 2020, 108, 103533. [CrossRef]

17. Gursel, A.P.; Maryman, H.; Ostertag, C. A life-cycle approach to environmental, mechanical, and durability properties of 'green' concrete mixes with rice husk ash. J. Clean. Prod. 2016, 112, 823-836. [CrossRef]

18. Moraes, C.A.M.; Kieling, A.G.; Caetano, M.O.; Gomes, L.P. Life cycle analysis (LCA) for the incorporation of rice husk ash in mortar coating. Resour. Conserv. Recycl. 2010, 54, 1170-1176. [CrossRef]

19. Rahman, M.E.; Muntohar, A.S.; Pakrashi, V.; Nagaratnam, B.H.; Sujan, D. Self compacting concrete from uncontrolled burning of rice husk and blended fine aggregate. Mater. Des. 2014, 55, 410-415. [CrossRef]

20. Prasara, J.-A.; Grant, T. Comparative life cycle assessment of uses of rice husk for energy purposes. Int. J. Life Cycle Assess. 2011, 16, 493-502. [CrossRef]

21. Saraswathy, V.; Song, H.-W. Corrosion performance of rice husk ash blended concrete. Constr. Build. Mater. 2007, 21, 1779-1784. [CrossRef]

22. Javed, M.F.; Amin, M.N.; Shah, M.I.; Khan, K.; Iftikhar, B.; Farooq, F.; Aslam, F. Applications of Gene Expression Programming and Regression Techniques for Estimating Compressive Strength of Bagasse Ash based Concrete. Crystals 2020, 10, 737. [CrossRef]

23. Ahmad, A.; Farooq, F.; Niewiadomski, P.; Ostrowski, K.; Akbar, A.; Aslam, F.; Alyousef, R. Prediction of Compressive Strength of Fly Ash Based Concrete Using Individual and Ensemble Algorithm. Materials 2021, 14, 794. [CrossRef]

24. Hammoudi, A.; Moussaceb, K.; Belebchouche, C.; Dahmoune, F. Comparison of artificial neural network (ANN) and response surface methodology (RSM) prediction in compressive strength of recycled concrete aggregates. Constr. Build. Mater. 2019, 209, 425-436. [CrossRef]

25. Jalal, M.; Arabali, P.; Grasley, Z.; Bullard, J.W.; Jalal, H. Behavior assessment, regression analysis and support vector machine (SVM) modeling of waste tire rubberized concrete. J. Clean. Prod. 2020, 273, 122960. [CrossRef]

26. Nehdi, Y.D.M.; Khan, A. Neural Network Model for Preformed-Foam Cellular Concrete. ACI Mater. J. 2001, 98, 5. [CrossRef]

27. Atici, U. Prediction of the strength of mineral admixture concrete using multivariable regression analysis and an artificial neural network. Expert Syst. Appl. 2011, 38, 9609-9618. [CrossRef]

28. Yaseen, Z.M.; Deo, R.C.; Hilal, A.; Abd, A.M.; Bueno, L.C.; Salcedo-Sanz, S.; Nehdi, M.L. Predicting compressive strength of lightweight foamed concrete using extreme learning machine model. Adv. Eng. Softw. 2018, 115, 112-125. [CrossRef]

29. Deng, F.; He, Y.; Zhou, S.; Yu, Y.; Cheng, H.; Wu, X. Compressive strength prediction of recycled concrete based on deep learning. Constr. Build. Mater. 2018, 175, 562-569. [CrossRef]

30. Bachir, R.; Mohammed, A.M.S.; Habib, T. Using Artificial Neural Networks Approach to Estimate Compressive Strength for Rubberized Concrete. Period. Polytech. Civ. Eng. 2018, 62, 858-865. [CrossRef]

31. Altun, F.; Kişi, Ö.; Aydin, K. Predicting the compressive strength of steel fiber added lightweight concrete using neural network. Comput. Mater. Sci. 2008, 42, 259-265. [CrossRef] 
32. Perera, R.; Barchín, M.; Arteaga, A.; Diego, A.D. Prediction of the ultimate strength of reinforced concrete beams FRP-strengthened in shear using neural networks. Compos. Part B Eng. 2010, 41, 287-298. [CrossRef]

33. Tanarslan, H.M.; Secer, M.; Kumanlioglu, A. An approach for estimating the capacity of RC beams strengthened in shear with FRP reinforcements using artificial neural networks. Constr. Build. Mater. 2012, 30, 556-568. [CrossRef]

34. Öztaş, A.; Pala, M.; Özbay, E.; Kanca, E.; Caglar, N.; Bhatti, M.A. Predicting the compressive strength and slump of high strength concrete using neural network. Constr. Build. Mater. 2006, 20, 769-775. [CrossRef]

35. Bui, D.D.; Hu, J.; Stroeven, P. Particle size effect on the strength of rice husk ash blended gap-graded Portland cement concrete. Cem. Concr. Compos. 2005, 27, 357-366. [CrossRef]

36. Ganesan, K.; Rajagopal, K.; Thangavel, K. Rice husk ash blended cement: Assessment of optimal level of replacement for strength and permeability properties of concrete. Constr. Build. Mater. 2008, 22, 1675-1683. [CrossRef]

37. Ramezanianpour, A.A.; Mahdikhani, M.; Ahmadibeni, G. The Effect of Rice Husk Ash on Mechanical Properties and Durability of Sustainable Concretes. Int. J. Civ. Eng. 2009, 7, 83-91. Available online: https://www.sid.ir/en/journal/ViewPaper.aspx?ID= 140499 (accessed on 12 September 2020).

38. Sakr, K. Effects of Silica Fume and Rice Husk Ash on the Properties of Heavy Weight Concrete. J. Mater. Civ. Eng. 2006, 18, 367-376. [CrossRef]

39. De Sensale, G.R. Strength development of concrete with rice-husk ash. Cem. Concr. Compos. 2006, 28, 158-160. [CrossRef]

40. Golafshani, E.M.; Behnood, A.; Arashpour, M. Predicting the compressive strength of normal and High-Performance Concretes using ANN and ANFIS hybridized with Grey Wolf Optimizer. Constr. Build. Mater. 2020, 232, 117266. [CrossRef]

41. Golafshani, E.M.; Behnood, A. Automatic regression methods for formulation of elastic modulus of recycled aggregate concrete. Appl. Soft Comput. 2018, 64, 377-400. [CrossRef]

42. Jaafari, A.; Panahi, M.; Pham, B.T.; Shahabi, H.; Rezaie, F.; Lee, S. Meta optimization of an adaptive neuro-fuzzy inference system with grey wolf optimizer and biogeography-based optimization algorithms for spatial prediction of landslide susceptibility. CATENA 2019, 175, 430-445. [CrossRef]

43. Gandomi, A.H.; Roke, D.A. Assessment of artificial neural network and genetic programming as predictive tools. Adv. Eng. Softw. 2015, 88, 63-72. [CrossRef]

44. Alavi, A.H.; Gandomi, A.H. Prediction of principal ground-motion parameters using a hybrid method coupling artificial neural networks and simulated annealing. Comput. Struct. 2011, 89, 2176-2194. [CrossRef]

45. Çaydaş, U.; Hasçalık, A.; Ekici, S. An adaptive neuro-fuzzy inference system (ANFIS) model for wire-EDM. Expert Syst. Appl. 2009, 36 Pt 2, 6135-6139. [CrossRef] 